\title{
Sero-prevalence of human
}

Hussein Mukasa Kafeero ${ }^{1,2^{*}}$, Dorothy Ndagire ${ }^{3}$, Ponsiano Ocama ${ }^{4}$, Abdul Walusansa ${ }^{2}$ and Hakim Sendagire Hed $^{1,2}$

\begin{abstract}
Background: There is plenitude of information on HIV infection among pregnant mothers attending antenatal care (ANC) in sub-Saharan Africa. However, the epidemiology of HBV-HIV co-infections in the same cohort is not clear despite the common route of transmission of both viruses. The aim of our study was to synthesize data on the prevalence of HBV-HIV co-infection among pregnant women attending ANC in Sub-Saharan Africa to assist in the design of public health interventions to mitigate the challenge.

Methods: The study was done in tandem with the Preferred Reporting Items for Systematic Reviews and Meta-analyses (PRISMA) standards and the Cochran's Q test, $I^{2}$ statistics for heterogeneity and the prevalence were calculated using commercially available software called MedCalcs (https://www.medcalc.org). A random effect model was used to pool the prevalence since all the heterogeneities were high $(\geq 78 \%)$ and $\mathrm{P}_{\text {het }}<0.05$ indicated significant heterogeneities. The risk factors and risk differences for HBV-HIV co-infection were analyzed. Any likely sources of heterogeneity were analyzed through sensitivity analysis, meta-regression and sub-group analysis. All analyses were done at 95\% level of significance and a $P<0.05$ was considered significant.
\end{abstract}

Results: The overall pooled prevalence of HBV-HIV co-infection among pregnant mothers in sub-Saharan Africa was low $3.302 \%(95 \% \mathrm{Cl}=2.285$ to $4.4498 \%)$ with heterogeneities $\left(1^{2}\right)$ of $97.59 \%(P>0.0001)$. Within regional sub group meta-analyses, West Africa had significantly higher prevalence of $5.155 \%(95 \%=2.671$ to $8.392 \%)$ with heterogeneity $\left(I^{2}\right)$ of $92.25 \%(P<0.0001)$ than any other region $(P<0.001)$. Articles published from 2004-2010 had significantly higher prevalence of $6.356 \%(95 \%=3.611$ to $9.811 \%)$ with heterogeneity $\left(I^{2}\right) 91.15 \%(P<0.0001)$ compared to those published from 2011 to $2019(P<0.001)$. The HIV positive cohort had significantly higher prevalence of HBV-HIV co-infection of $8.312 \%(95 \% \mathrm{Cl}=5.806$ to $11.22 \%)$ with heterogeneity $\left(1^{2}\right) 94.90 \%(P<0.0001)$ than the mothers sampled from the general population with a prevalence of $2.152 \%(95 \% \mathrm{Cl}=1.358$ to $3.125 \%)(P<0.001)$. The overall and sub group

*Correspondence: husseinmukasakafeero@gmail.com

1 Department of Medical Microbiology, College of Health Sciences,

Makerere University, P.O Box 7062, Kampala, Uganda

Full list of author information is available at the end of the article

(c) The Author(s) 2020. Open Access This article is licensed under a Creative Commons Attribution 4.0 International License, which permits use, sharing, adaptation, distribution and reproduction in any medium or format, as long as you give appropriate credit to the original author(s) and the source, provide a link to the Creative Commons licence, and indicate if changes were made. The images or other third party material in this article are included in the article's Creative Commons licence, unless indicated otherwise in a credit line to the material. If material is not included in the article's Creative Commons licence and your intended use is not permitted by statutory regulation or exceeds the permitted use, you will need to obtain permission directly from the copyright holder. To view a copy of this licence, visit http://creativecommons.org/licenses/by/4.0/. The Creative Commons Public Domain Dedication waiver (http://creativeco mmons.org/publicdomain/zero/1.0/) applies to the data made available in this article, unless otherwise stated in a credit line to the data. 
analyses had high heterogeneities $\left(I^{2}>89 \%, P<0.0001\right)$ but was reduced for South Africa $\left(I^{2}\right)=78.4 \%(P=0.0314)$. Age, marital status and employment were independent factors significantly associated with risk of HBV-HIV co-infection $(P<0.001)$ but not extent of gravidity and education level $(P>0.05)$. After meta-regression for year of publication and sample size for HBsAg positivity, the results were not significantly associated with HBV pooled prevalence for sample size $(P=0.146)$ and year of publication $(P=0.560)$. Following sensitivity analysis, the $\mathrm{HBsAg}$ pooled prevalence slightly increased to $3.429 \%(95 \% \mathrm{Cl}=2.459$ to $4.554 \%)$ with heterogeneity $\mathrm{I}^{2}=96.59 \%(95 \% \mathrm{Cl}=95.93$ to $97.14 \%), \mathrm{P}<0.0001$

Conclusion: There is an urgent need for routine HBV screening among HIV positive pregnant mothers attending antenatal care in sub-Saharan Africa to establish the extent of HBV-HIV co-infection in this cohort. Future studies need to investigate the putative risk factors for HBV-HIV co-infection and prioritize plausible control strategies.

Keyword: Antenatal care, HBV-HIV co-infection, Pregnant mothers, Sub-Saharan Africa

\section{Introduction}

Sub-Saharan Africa (SSA) is the epicenter of many infectious diseases including Human Immunodeficiency Virus (HIV) and Hepatitis B Virus (HBV) [1, 2]. The world Health Organization (WHO) estimates that $70-95 \%$ of the adult population in sub-Saharan Africa is exposed to HBV with Hepatitis B Surface Antigen (HBsAg) seroprevalence rates of $6-20 \%$ [3]. Similarly, more than 25.6 million people in SSA are living with HIV [4]. The HIV and HBV share the same route of transmission making co-infection with both viruses plausible. The global burden of HBV-HIV co-infection is estimated at 2.6 million people with prevalencies ranging from 10 to $25 \%$ in moderate endemic to high endemic regions of SSA [5]. The Viral interactions in HIV-HBV co-infection complicate antiviral therapy [6] and reduce the Cluster of Differentiation (CD) -4 count [7]. Patients infected with hepatitis $B$ virus show rapid progression of HIV infection clinical signs and are at a higher risk of liver cell damage compared to HIV mono-infection due to combined antiretroviral therapy (cART) [6]. Similarly, HIV patients when exposed to HBV show rapid progression of liver inflammation including cirrhosis, fibrosis and liver cancer compared to HBV mono-infection [8].

The impact of the HIV-HBV co-infection during pregnancy on mother's health and the fetal pre-natal as well as post-natal life, mother-to-child-transmission (MTCT) of either virus or both is not fully understood $[7,9,10]$. However, the HIV-HBV co-infection during pregnancy impairs CD8+ T-cell and CD4+ T-cell specific HBV responses compared to mono-infection with HBV [11] exacerbating development of chronic HBV disease in the HBV-HIV co-infected [12]. Moreover, HBV-HIV co-infection has been implicated in accelerated hepatic apoptosis and fibrosis [13] increasing morbidity and mortality [6]. The effects of maternal HBV-HIV co-infection on the new born are diverse. Firstly, HBV infected children born to HBV-HIV co-infected mothers are at an increased risk of liver complications and liver diseases related death than those born from HBV mono-infected mothers [14]. Secondly, HBV-HIV co-infection escalates $\mathrm{HBV}$ replication and hepatitis $\mathrm{B}$ pre-core antigen (HBeAg) sero-positivity [6] increasing viral load augmenting the risk of MTCT of HBV $[15,16]$. Moreover, the risk of mother-to-child transmission is $70-90 \%$ for $\mathrm{HBeAg}$ positive mothers compared to $10-40 \%$ for HBeAg negative mothers [17]. Unfortunately, 90-95\% of the children who acquire HBV through the perinatal route progress to chronic infection later in life with increased risk of development of end stage liver diseases [16]. Therefore, understanding the HBV-HIV co-infection prevalence during pregnancy in our region and subsequent initiation of strategies to prevent MTCT of HBV should be of urgent attention by all health systems in SSA countries.

Whereas in most SSA countries HIV is routinely tested for in pregnant women attending antenatal care (ANC), HBsAg screening in the same cohort is not routine despite their overlapping routes of transmission [18-20]. This has hampered the design of interventions to mitigate the effect of HBV-HIV co-infection in pregnancy since the epidemiological data on the HBV-HIV co-infection among pregnant woman in SSA is scanty [21].

Failure to prevent MTCT of HBV from risky HBV-HIV co-infected pregnant mothers will culminate into a pool of HBV perinatal acquired infected children who will be a pool of continuous transmission to others. Thus information on the sero-prevalence of HBV-HIV co-infection among pregnant women is SSA is absolutely necessary for effective implementation of the control strategies.

The major aim of our meta-analysis was to estimate the prevalence of HBV-HIV co-infection among pregnant mothers in SSA following the common notion that most of HBV infections are co-infected with HIV due to the shared routes of transmission of the viruses. So, the study compared the prevalence of HBV-HIV co-infection among pregnant women on ANC in SSA with the prevalence reported in studies carried out elsewhere in the same cohort in order to assess the burden of the infection in our region and inform health care professionals, 
researchers and policy makers on the status quo of the HBV-HIV co-infection in this risky group of pregnant mothers. The SSA region has four sub-regions of East, West, Central and Southern Africa [22]. In East Africa (Ethiopia, Malawi, Rwanda, Tanzania and Uganda), in West Africa (Burkina Faso, Ivory coast, Ghana, Mali and Nigeria), in Central Africa (Cameroon and Democratic Republic of Congo) and in Southern Africa only South Africa had representative studies on the HBVHIV co-infection in the data base for inclusion in our meta-analysis.

\section{Materials and methods}

\section{Journal article search strategy}

This study was done in tandem with the Preferred Reporting Items for Systematic Reviews and Meta-analyses (PRISMA) standards (Fig. 1). Relevant studies were identified by a search of PubMed, Google scholar and ScienceDirect, as well as manual search in the references of the studies identified. The search was conducted from March 2020 to June 2020 using the following Boolean search terms: HBV-HIV co-infection in East Africa, West African, Central Africa, South Africa, Benin, Burkina Faso, Cape Verde, Côte D'Ivoire, Gambia, Ghana,
Guinea, Guinea-Bissau, Liberia, Mali, Mauritania, Niger, Nigeria, Saint Helena, Senegal, Sierra Leone, Togo, Burundi, Comoros, Djibouti, Ethiopia, Eritrea, Kenya, Madagascar, Malawi, Mauritius, Mozambique, Réunion, Rwanda, Seychelles, Somalia, Somaliland, Tanzania, Uganda, Zambia, and Zimbabwe, Cameroon, Central African Republic, Chad, Congo Republic-Brazzaville, Democratic Republic of Congo, Equatorial Guinea, Gabon, São Tomé \& Principe, Zambia, Zimbabwe, Botswana, Namibia, HIV positive, HIV-HBV co-infection, Antenatal care and pregnant women. The search results yielded about 2560 journal articles.

\section{Selection of articles for meta-analysis}

The articles obtained were evaluated by two independent hepatitis B virus experts (HMK and DN) for their eligibility for inclusion in the study or exclusion from the study in line with the aim of the study.

\section{Inclusion criteria}

The papers included in the study were selected after meeting the following preconditions; must have been a case-control or cohort study, testing for HBsAg, full text articles, from sub-Saharan Africa and published in
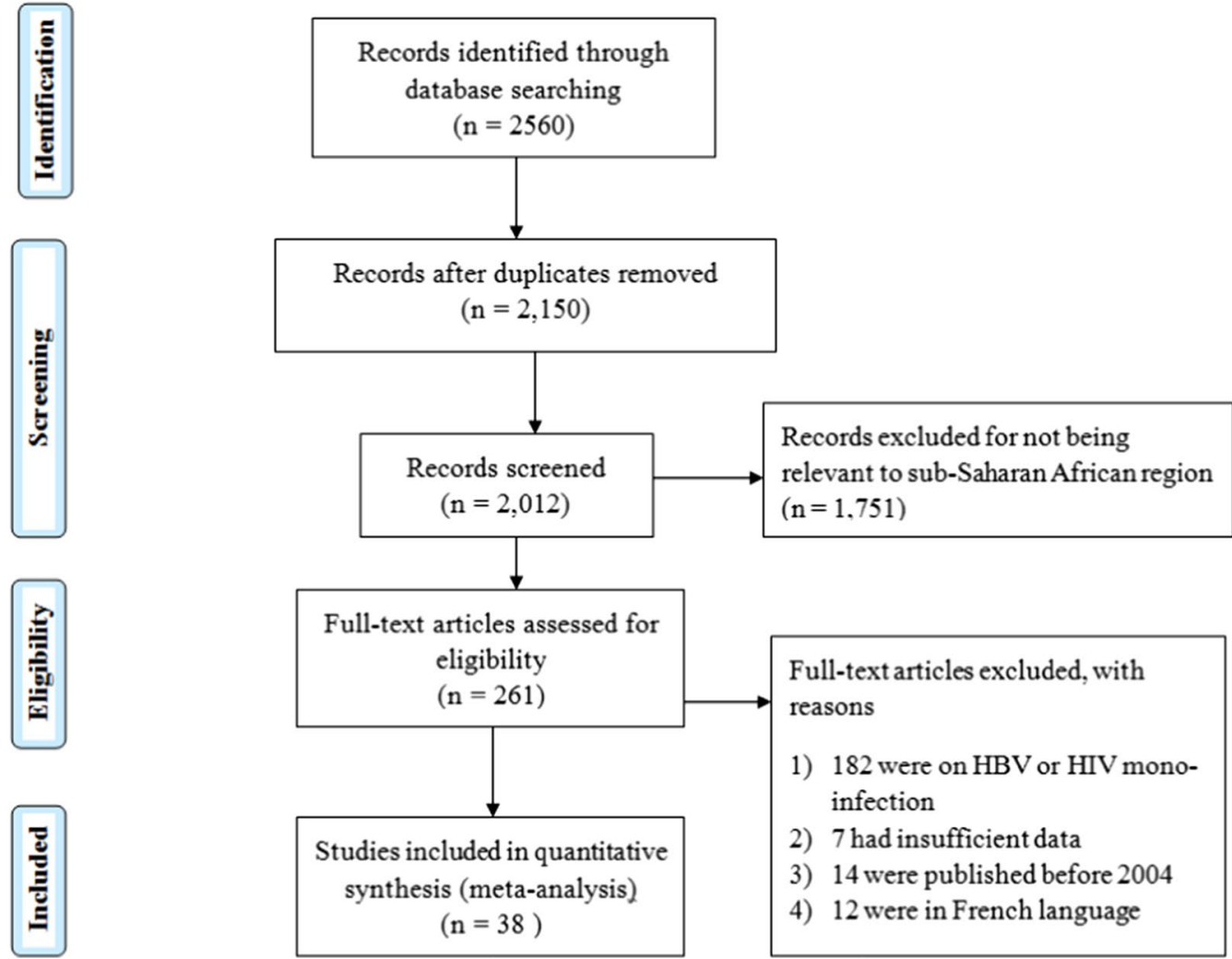

Fig. 1 Flow chart for study eligibility following PRISMA criterion 
peer-reviewed journals between the period of 2004 to 2019 in English language with sample size $>20$ targeting HBV-HIV co-infected pregnant women on antenatal care in the general population or in the HIV positive cohort.

\section{Exclusion criteria}

Articles excluded from the study included pre-prints, articles with sample size $<20$, those with insufficient data, the studies whose main data could not be obtained, those investigating other viral hepatitis (C, D or E), reviews/ meta-analyses, studies that detected hepatitis B core antigen (HBcAg), studies in other languages other than English, those published before 2004 and after 2019, studies targeting HBV mono-infection or HIV mono-infection or those conducted outside sub-Saharan Africa.

\section{Extracting data from the journal articles}

Three of the authors (HMK, AW and DN) designed a protocol for the selection criteria aforementioned above. Both reviewers extracted data independently and entered the data in the spread sheet pending analysis. The two authors compared their records after the review of the journal articles and any differences were resolved by consensus. In our meta-analysis, the following characteristics were recorded for each study; first author, year of publication, country, study design, sampling technique, sample size, HBV-HIV co-infection and quality score.

\section{Quality assessment}

The quality of each study was assessed by three independent reviewers (HMK, AW and DN) and the Newcastle-Ottawa scale was used [23]. Two authors (PO and HS) supervised the work of the HMK, AW and DN to ensure consistence in the quality of the work assessed. Three dimensions of comparability, selection and exposure were considered as described in the NewcastleOttawa scale. Studies were assigned scores ranging from the worst of zero to the best of 9. Studies with scores 9-8 were considered high quality studies, those between 7 and 6 were considered satisfactory whereas those with scores $\leq 5$ were unsatisfactory and were rejected.

\section{Data analysis}

Cochran's Q test and I ${ }^{2}$ statistics were performed using the commercially available software (https://www.medca lc.org) to evaluate the extent of heterogeneity of all the eligible studies for meta-analysis. There was high heterogeneity among the pooled studies $\left(\mathrm{I}^{2} \geq 78 \%\right)$ and the random effect model was used to pool the prevalence [24-26]. The prevalence for each study and 95\% CI were calculated and the pooled prevalence estimate was determined. Some representative results were presented graphically using forest plots. The prevalence of each study in the forest plot is indicated by the purple circle/square. The size of the circle/square represents the weight contributed by each study in the meta-analysis. The pooled prevalence for random effect model is shown by the red diamond. The publication bias was assessed by carrying out funnel plots. Sources of heterogeneity were analyzed through sensitivity analysis, meta-regression and sub-group analysis. All analyses were performed using the statistical software, MedCalc available at https ://www.medcalc.org

\section{Results}

The PRISMA strategy (Fig. 1) was used to screen for the eligible studies. In total, 38 (thirty-eight) articles with a total sample size of 44,114 (forty-four thousand one hundred fourteen) pregnant women attending antenatal care and 1047 (one thousand forty-seven) HBV-HIV coinfected pregnant mothers.

In our meta-analysis, 13(thirteen) eligible studies were from East African region [27-38], sixteen (16) studies were from West African region [18, 39-53], 2 (two) studies were from South African region [14, 54] and 7 (seven) studies were from Central African region [55-61]. In East Africa, five (5) studies were from Ethiopia [27-31], 2 (two) from Malawi [32, 33], 2 (two) from Rwanda [34, 35], 1 (one) from Tanzania [36] and 3 (three) from Uganda [35, 37, 38]. In West Africa, 2 (two) studies were from Burkina Faso [39, 40], 3 (three) from Ghana [41-43], 1 (one) from Ivory Coast [44], 1 (one) from Mali [45] and 9 (nine) from Nigeria [18, 46-53]. In southern Africa region, both studies were from South Africa [14, 54]. Finally, in Central Africa, 6 (six) studies were from Cameroon [55-60] and 1(one) eligible study was from Democratic republic of Congo [61] (Table 1).

Majority of the studies included in our meta-analysis (30/38) or $78.95 \%$ were published from 2011 to 2019 [14, $18,27-34,36-38,41-43,45-47,50,51,53-61]$ and a few studies $(8 / 38)$ or $21.05 \%$ were published from 2004 to 2010 [35, 39, 40, 44, 48, 49, 52]. Additionally, most studies; 27/38 (71\%) were conducted on pregnant mothers on ANC from the general population [14, 27-31, 34-42, 45, $47-52,54,56,58-60]$ whereas a few of the studies; $11 / 38$ (29\%) used HIV positive mothers to survey for the prevalence of HBV-HIV co-infection among ANC attendees in SSA [18, 32, 33, 43, 44, 46, 53, 55, 57, 61].

Finally, 19 (nineteen) of the eligible studies detected the HBsAg using Enzyme Linked Immunosorbent Assay (ELISA) [26, 27, 31, 33, 35, 37, 39, 41, 43, 46-50, 52, 54, 56, 59], 13 (thirteen) used Rapid Diagnostic Techniques (RDT) $[18,29,30,38,40,42,45,51,53,55,58,60,61]$ and 3 (three) used Abbott ARCHITECT system (AAS) [38, 40, 59], 1 (one) Vitros Chemiluminescence Immunoassay 
Table 1 Characteristics of the eligible studies

\begin{tabular}{|c|c|c|c|c|c|c|c|}
\hline First author, year & Country & Study design & Sampling technique & Sample & $\begin{array}{l}\text { HBV/HIV } \\
\text { co-infection }\end{array}$ & $\begin{array}{l}\text { Diagnostic } \\
\text { Method }\end{array}$ & QS \\
\hline Andersson et al. [14] & South Africa & Cross-section & Purposive & 3089 & 53 & ELISA & 8 \\
\hline Bafa et al. [27] & Ethiopia & Cross-section & Random & 222 & 4 & RDT & 9 \\
\hline Chasela et al. [32] & Malawi & Cross-section & Entire & 2048 & 103 & ELISA & 9 \\
\hline Desalegn et al. [28] & Ethiopia & Cross-section & Entire & 202 & 1 & EIA & 6 \\
\hline Dionne-Odom et al. [60] & Cameroon & Cross-section & Consecutive & 7069 & 205 & RDT & 9 \\
\hline Ezechi et al. [46] & Nigeria & Cross-section & Purposive & 2391 & 101 & ELISA & 9 \\
\hline Ilboudo et al. [39] & Burkina Faso & Cross-section & Purposive & 115 & 14 & RDT & 6 \\
\hline Mbaawuaga et al. [47] & Nigeria & Cross-section & Purposive & 507 & 5 & RDT & 7 \\
\hline Mpody et al. [61] & DR Congo & Cross-section & Entire & 1377 & 65 & ELISA & 8 \\
\hline Abwonga et al. [55] & Cameroon & Cross-section & Entire & 301 & 5 & RDT & 7 \\
\hline Adesina et al. [48] & Nigeria & Cross-section & Entire & 721 & 64 & ELISA & 7 \\
\hline Amsalu et al. [29] & Ethiopia & Cross-section & Purposive & 475 & 10 & RDT & 8 \\
\hline Andreotti et al. [33] & Malawi & Cross-section & Entire & 309 & 28 & RDT & 7 \\
\hline Bassey et al. [49] & Nigeria & Cross-section & Purposive & 500 & 36 & ELISA & 8 \\
\hline Bayo et al. [37] & Uganda & Cross-section & Random & 402 & 4 & ELISA & 7 \\
\hline Dabsu et al. [30] & Ethiopia & Cross-section & Convenient & 421 & 1 & RDT & 8 \\
\hline Fomulu et al. [56] & Cameroon & Cross-section & Consecutive & 959 & 7 & ELISA & 8 \\
\hline Frempong et al. [41] & Ghana & Cross-section & Consecutive & 248 & 22 & EIA & 8 \\
\hline Helegbe et al. [42] & Ghana & Cross-section & Purposive & 3127 & 1 & VCIA & 9 \\
\hline Ikeako et al. [50] & Nigeria & Retrospective & Entire & 1239 & 3 & ELISA & 9 \\
\hline Kfutwah et al. [57] & Cameroon & Cross-section & Entire & 650 & 28 & RDT & 8 \\
\hline Lar et al. [18] & Nigeria & Cross-section & Entire & 135 & 16 & ELISA & 8 \\
\hline MacLean et al. [45] & Mali & Cross-section & Entire & 3659 & 14 & ELISA & 8 \\
\hline Manyahi et al. [36] & Tanzania & Cross-section & Consecutive & 249 & 7 & ELISA & 8 \\
\hline Mutagoma et al. [34] & Rwanda & Cross-section & Entire & 13,121 & 20 & ELISA & 9 \\
\hline Noubiap et al. [58] & Cameroon & Cross-section & Consecutive & 325 & 5 & RDT & 7 \\
\hline Ntiamoah et al. [43] & Ghana & Cross-section & Purposive & 124 & 11 & RDT & 6 \\
\hline Ojiegbe et al. [51] & Nigeria & Cross-section & Purposive & 300 & 3 & ELISA & 6 \\
\hline Pirillo et al. [35] & Rwanda & Cross-section & Entire & 82 & 2 & RDT & 7 \\
\hline Pirillo et al. [35] & Uganda & Cross-section & Entire & 164 & 8 & ELISA & 7 \\
\hline Rouet et al. [44] & Ivory cost & Retrospective & Entire & 449 & 45 & ELISA & 8 \\
\hline Seremba et al. [38] & Uganda & Cross-section & Purposive & 612 & 9 & AAS & 7 \\
\hline Simpore et al. [40] & Burkina Faso & Cross-section & Entire & 336 & 24 & AAS & 7 \\
\hline Tanjong Re et al. [59] & Cameroon & Cross-section & Purposive & 406 & 6 & AAS & 8 \\
\hline Thumbiran et al. [54] & South Africa & Cross-section & Entire & 570 & 18 & ELISA & 6 \\
\hline Usanga et al. [52] & Nigeria & Cross-section & Purposive & 562 & 5 & ELISA & 8 \\
\hline Ya'aba et al. [53] & Nigeria & Cross-section & Purposive & 330 & 90 & ELISA & 7 \\
\hline Zenebe et al. [31] & Ethiopia & Cross-section & Random & 318 & 4 & RDT & 9 \\
\hline
\end{tabular}

VCIA vitros chemi luminescent immunoassay, AAS abbott ARCHITECT system, ELISA enzyme linked immuno assay, EIA enzyme immuno assay, RDT rapid diagnostic test, QS quality score

(VCIA) [42] and 2 (two) Enzyme Immuno Assay (EIA) $[28,41]$.

\section{Prevalence of HBV-HIV co-infection among pregnant mothers in Sub-Saharan African region}

The prevalence of HBV-HIV co-infection in Sub-Saharan African region varied widely with the highest prevalence reported among HIV positive pregnant mothers on ANC compared to pregnant mothers on ANC from the general population. Among the HIV positive mothers, the HBV-HIV co-infection prevalence ranged from $1.661 \%$ (95\% $\mathrm{CI}=0.542$ to $3.834 \%)$ in 301(three hundred one) Cameroonian mothers on ANC [55] to 27.273\% $(95 \% \mathrm{CI}=22.593$ to $32.420 \%)$ in a sample of 330 (three 
hundred thirty) Nigerian pregnant mothers [53]. On the other hand, HBV-HIV co-infection prevalence among mothers from the general population ranged from $0.03 \%$ ( $95 \% \mathrm{CI}=0.00081$ to $0.178 \%$ ) in a sample of 3,127 (three thousand one hundred twenty-seven) Ghanaian mothers on ANC [42] to $12.174 \%$ ( $95 \% \mathrm{CI}=6.818$ to $19.582 \%)$ in a sample of 115 (one hundred fifteen) Burkinabé mothers on ANC [39].

However, the overall pooled prevalence of HBV-HIV co-infected was $3.303 \%$ ( $95 \% \mathrm{CI}=2.285$ to $4.498 \%$ ) among the sample of 44,114 (forty-four thousand one hundred fourteen) with heterogeneities $\left(\mathrm{I}^{2}\right)$ of $97.59 \%$ $(P>0.0001)$ (Fig. 2).

The funnel plot displayed a symmetric spread of studies in terms of relative weight and effect size despite the significant heterogeneity $(P<0.0001)$, thereby indicating little evidence of publication bias (Fig. 3).

\section{Sub-group meta-analysis}

We sub divided our meta-analysis into groups which included sub-Saharan African regions, year of publication, HIV + cohort or not and HBsAg diagnostic method (Table.2). In all sub-group meta-analyses, the heterogeneity remained high $\left(\mathrm{I}^{2}>89 \%, P<0.0001\right)$ except for

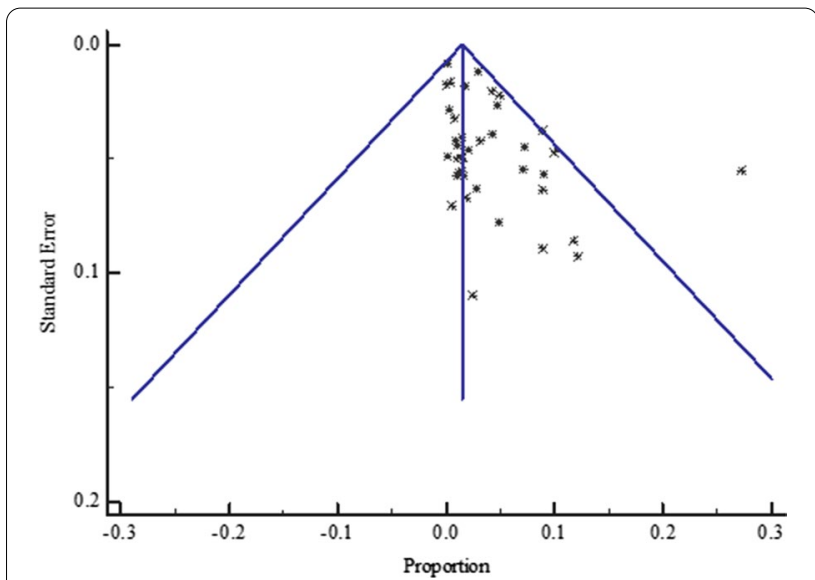

Fig. 3 Bias assessment funnel plot for HBV-HIV co-infection prevalence among pregnant mothers on antenatal care in Sub-Saharan Africa 2004 to 2019

South Africa with a lowered heterogeneity $\left(\mathrm{I}^{2}=78.40 \%\right.$, $P=0.00314)$. By region, the highest and the lowest pooled prevalence estimate of HBV-HIV co-infection among pregnant women attending antenatal care were registered from West Africa, 5.155\% $(95 \% \mathrm{CI}=2.671$ to

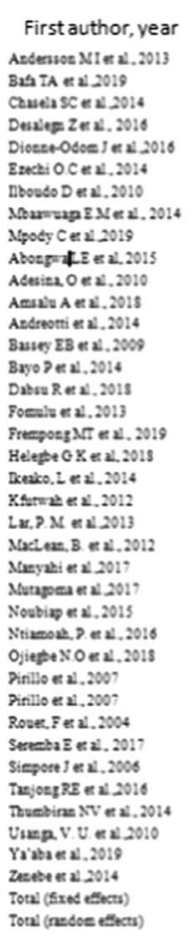

Toul (nedoesticas)

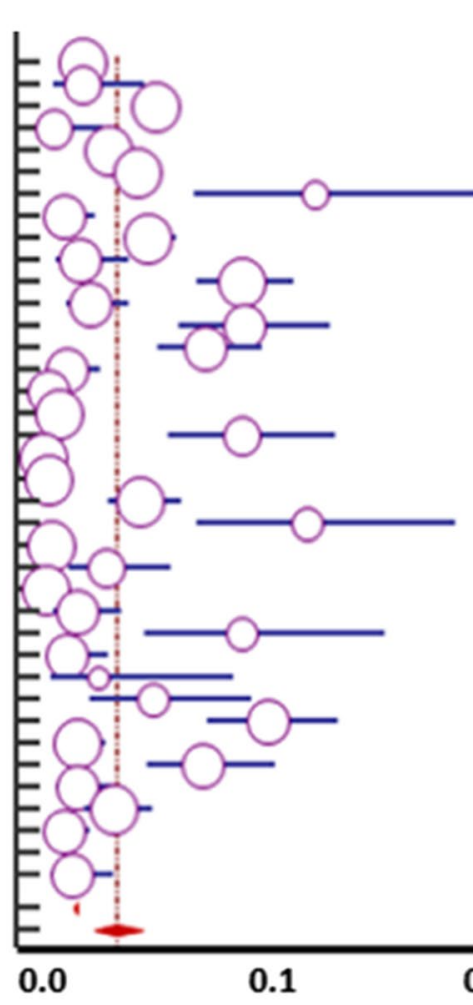

0.1

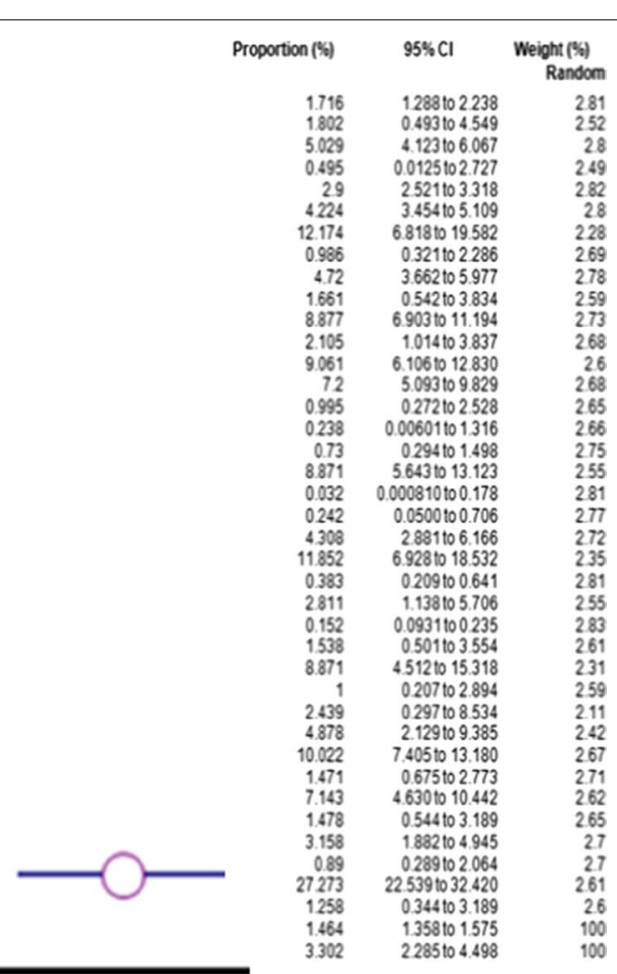

0.2 Proportion

Fig. 2 Forest plot for the Pooled prevalence estimate of HBV-HIV co-infection among pregnant mothers on antenatal care in Sub-Saharan Africa from 2004-2019 by random effect model 
Table 2 Sub-group meta-analysis of the HBV-HIV co-infection pooled prevalence estimation among ANC attendees

\begin{tabular}{|c|c|c|c|c|c|}
\hline \multirow[t]{2}{*}{ Variable } & \multicolumn{5}{|l|}{ Analysis } \\
\hline & number & Prevalence \% (95\% Cl) & $P$ value & $\mathrm{I}^{2}(\%)(95 \% \mathrm{Cl})$ & $P_{\text {het }}$ \\
\hline \multicolumn{6}{|l|}{ Region } \\
\hline West Africa & 16 & 5.16 (2.67 to 8.39) REF & & 92.25 (97.82 to 98.6$)$ & $P<0.0001$ \\
\hline East Africa & 13 & 2.168 (0.830 to 4.116$)$ & $<0.001^{*}$ & $96.79(95.68$ to 97.62$)$ & $P<0.0001$ \\
\hline South Africa & 2 & 2.317 (1.105 to 3.959$)$ & $<0.001^{*}$ & $78.4(6.03$ to 95.03$)$ & $P=0.0314$ \\
\hline Central Africa & 7 & 2.441 (1.492 to 3.617$)$ & $<0.001^{*}$ & $88.02(77.70$ to 93.57$)$ & $P<0.0001$ \\
\hline \multicolumn{6}{|c|}{ Year of publication } \\
\hline 2004-2010 & 8 & 6.356 (3.611 to 9.811$)$ & & 91.15(84.97 to 94.79$)$ & $P<0.0001$ \\
\hline 2011-2019 & 30 & $2.252(1.452$ to 3.221$)$ & $<0.001^{*}$ & $97.15(96.56$ to 97.64$)$ & $P<0.0001$ \\
\hline \multicolumn{6}{|l|}{ HIV + Cohort } \\
\hline Yes & 12 & 8.312 (5.806 to 11.22$)$ & & $94.90(92.69$ to 96.45$)$ & $P<0.0001$ \\
\hline No & 27 & 2.152 (1.358 to 3.125$)$ & $<0.001^{*}$ & 96.73(95.98 to 97.33) & $P<0.0001$ \\
\hline \multicolumn{6}{|c|}{ Detection method } \\
\hline ELISA & 19 & 3.39 (2.06 to 5.047) REF & & $93.80(91.64$ to 95.41$)$ & $P<0.0001$ \\
\hline RDT & 13 & 3.167 (1.484 to 5.449$)$ & 0.2996 & $98.01(97.44$ to 98.46$)$ & $P<0.0001$ \\
\hline Others & 6 & 3.323 (0.955 to 7.050$)$ & 0.7443 & 98.89(98.46 to 99.20$)$ & $P<0.0001$ \\
\hline
\end{tabular}

${ }^{*} P$ value is statistically significant, HIV = Human Immunodeficiency Virus, ELISA = Enzyme Linked Immuno Assay, RDT = Rapid Diagnostic Test

$8.392 \%$ ) in a sample of 14,743 (fourteen thousand seven hundred forty-three) and East Africa, 2.168\% (0.830 to $4.116 \%$ ) in a sample of 18,625 (eighteen thousand six hundred twenty-five) respectively.

The prevalence of HBV-HIV co-infection among pregnant women in West Africa varied from 0.0320\% (95\% $\mathrm{CI}=0.00081$ to $0.178 \%)$ reported in a study conducted in Ghana [42] to $27.273 \%$ ( $95 \% \mathrm{CI}=22.539$ to $32.420 \%$ ) reported in a study done in Nigeria [53] with pooled prevalence estimate of $5.155 \%$ (95\% CI $=2.671$ to $8.392 \%)$ in a sample of 14,743 (fourteen thousand seven hundred forty three) pregnant women attending antenatal care (Fig. 4, Table 2) and was significantly higher than any other region of sub-Saharan Africa $(P<0.001)$.

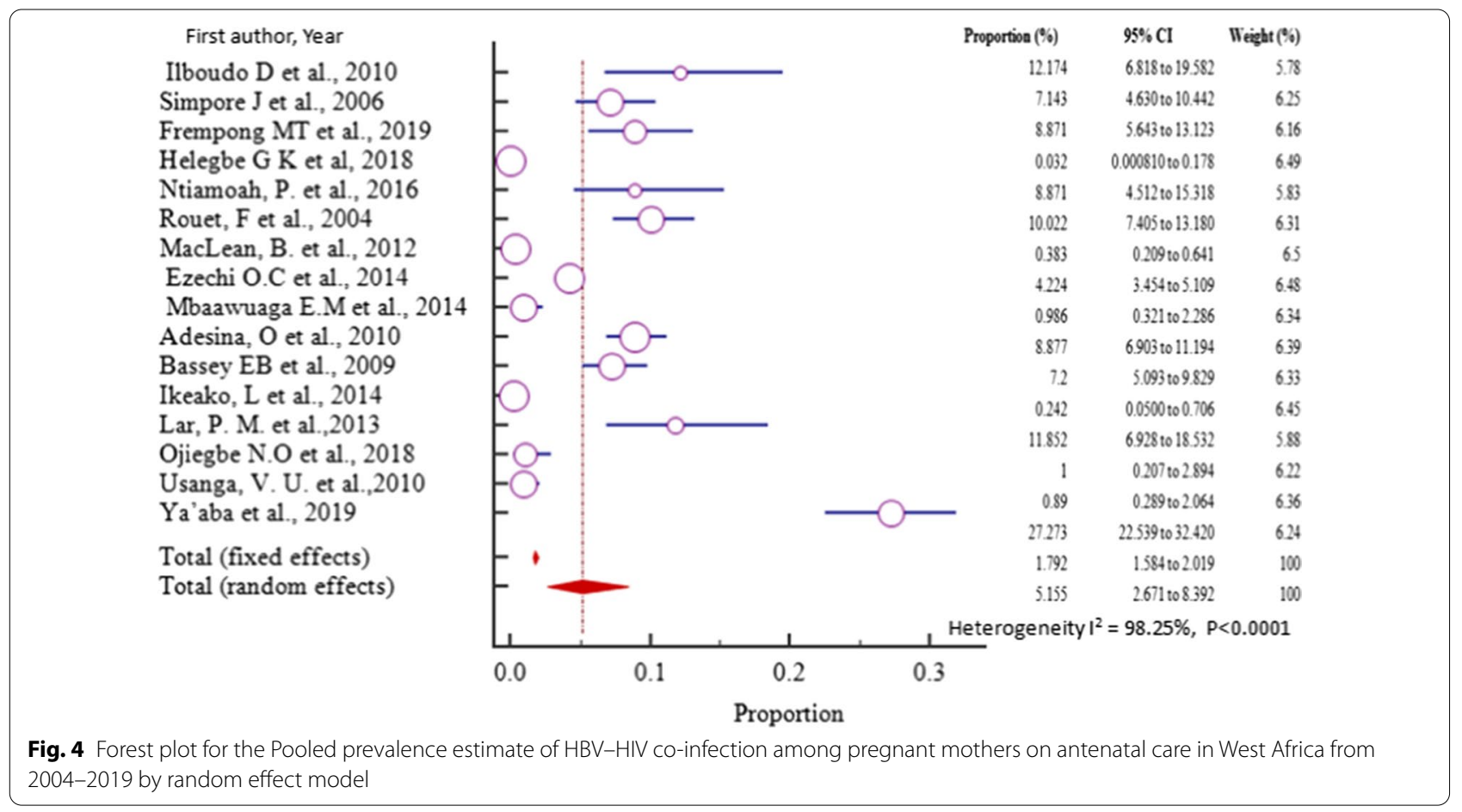


The funnel plot for all the West African studies published from 2004 to 2019 displayed a symmetric spread of studies in terms of relative weight and effect size despite the significant heterogeneity, $\mathrm{I}^{2}=98.25 \% \quad(P<0.0001)$, thereby indicating little evidence of publication bias (Fig. 5).

The prevalence of HBV-HIV co-infection among pregnant women on ANC in Central Africa varied from $0.73 \%(95 \% \mathrm{CI}=0.294$ to $1.498 \%)$ reported in a study conducted in Cameroon [56] to $4.72 \%(95 \% \mathrm{CI}=3.662$ to

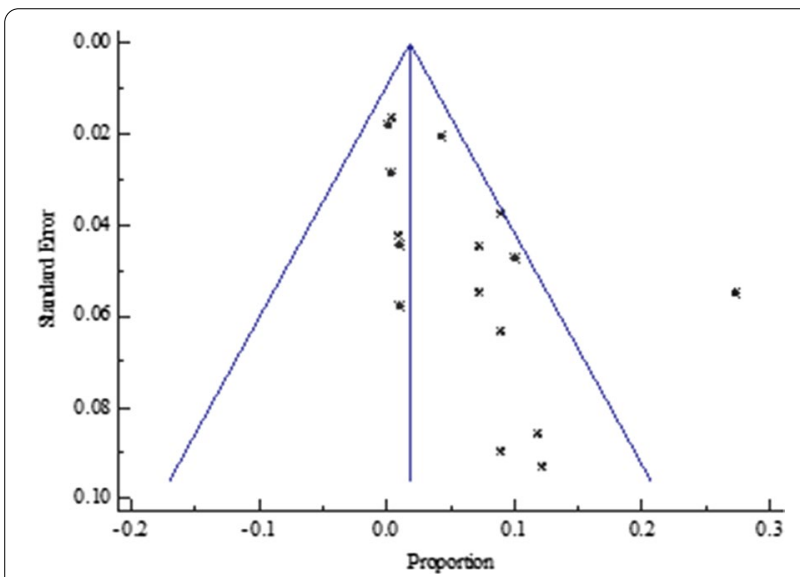

Fig. 5 Bias assessment funnel plot for HBV-HIV co-infection prevalence rate among pregnant mothers on antenatal care in West Africa 2004 to 2019
5.977\%) reported in a study done in Democratic Republic of Congo (DRC) [61] with pooled prevalence estimate of $2.441 \%(95 \% \mathrm{CI}=1.492$ to $3.617 \%)$ in a sample of 11,087 (eleven thousand eighty-seven) pregnant women attending antenatal care (Fig. 6, Table 2).

Similarly, the funnel plot for all the Central African studies published between 2012 to 2019 displayed a symmetric spread of studies in terms of relative weight and effect size despite the significant heterogeneity, $\mathrm{I}^{2}=88.02 \%(P<0.0001)$, thereby indicating little evidence of publication bias (Fig. 7).

The prevalence of HBV-HIV co-infection among pregnant women in East Africa varied from $0.152 \%(95 \%$ $\mathrm{CI}=0.0931$ to $0.235 \%$ ) reported in a study conducted in Rwanda from the general population [34] to $4.878 \%$ (95\% $\mathrm{CI}=2.129$ to $9.385 \%)$ in a related study conducted in Uganda [35] with pooled prevalence estimate of $2.168 \%$ (95\% CI $=0.830$ to $4.116 \%$ ) in a sample of 18,625 (eighteen thousand six hundred twenty-five) pregnant women attending antenatal care (Fig. 8, Table 2).

Again, the funnel plot for all the East African studies published from 2007 to 2019 displayed a symmetric spread of studies in terms of relative weight and effect size despite the significant heterogeneity, $\mathrm{I}^{2}=96.79 \%$ $(P<0.0001)$, thereby indicating little evidence of publication bias (Fig. 9).

The prevalence of HBV-HIV co-infection among pregnant women in South Africa varied from $1.716 \%$ (95\% CI $=1.288$ to $2.238 \%$ ) in a study conducted in

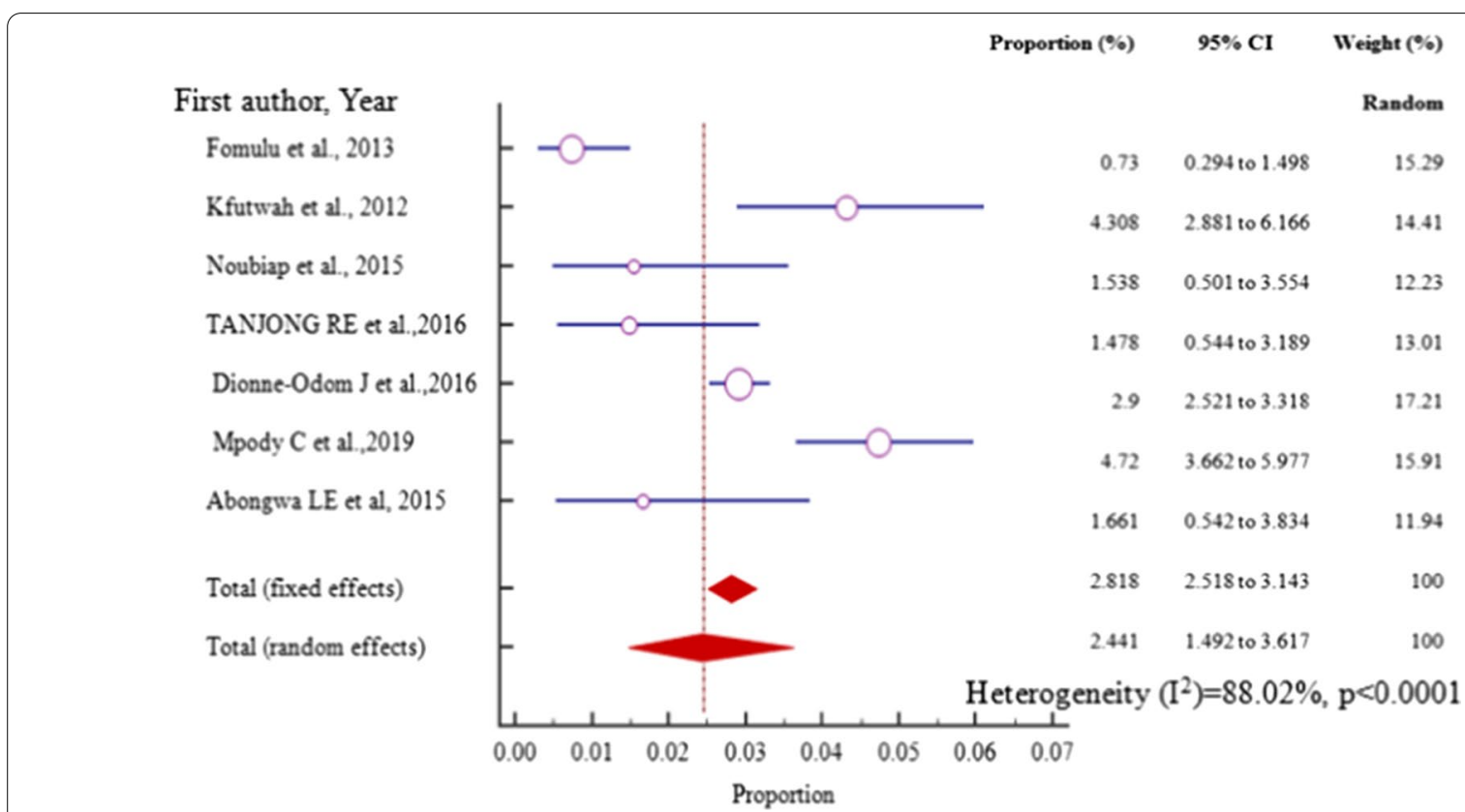

Fig. 6 Forest plot for the Pooled prevalence estimate of HBV-HIV among pregnant mothers on antenatal care in Central Africa from 2012-2019 by random effect model 


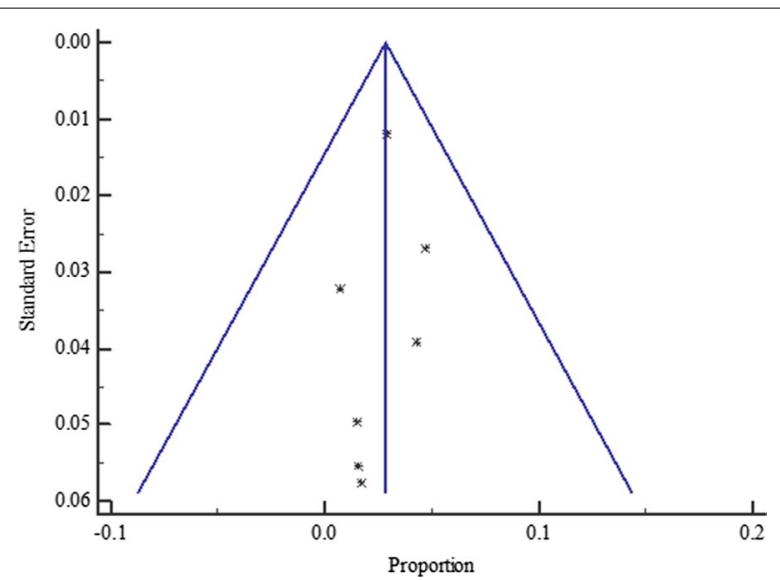

Fig. 7 Bias assessment funnel plot for HVB-HIV co-infection prevalence rate among pregnant mothers on antenatal care in Central Africa 2012 to 2019

south Africa from the general population [14] to 3.158\% $(95 \% \mathrm{CI}=1.882$ to $4.945 \%)$ in a study done in the same country and cohort [54] with pooled prevalence estimate of $2.317 \%(95 \% \mathrm{CI}=1.105$ to $3.959 \%)$ in a sample of 3,659 (three thousand six hundred fifty-nine) pregnant women on ANC (Fig. 10, Table 2).

As with the other regional subgroup meta-analyses, the funnel plot for the two South African studies published from 2013 to 2014 displayed a symmetric spread of studies in terms of relative weight and effect size despite the significant heterogeneity, $\mathrm{I}^{2}=78.4 \%$
$(P=0.0314)$, thereby indicating little evidence of publication bias (Fig. 11).

Regarding the year of publication, the lowest prevalence of $0.032 \%$ ( $95 \% \mathrm{CI}=0.000810$ to $0.178 \%)$ of $\mathrm{HBV}$ HIV co-infection in Sub-Saharan African region was reported in the study published in 2018 conducted from Ghana on 3,127 (three thousand one hundred twenty seven) pregnant mothers attending antenatal care [42] whereas the highest prevalence of $27.273 \%$ ( $95 \%$ $\mathrm{CI}=22.593$ to $32.420 \%$ ) was noted in a study published in 2019 conducted from Nigeria among 330 (three hundred thirty) HIV + pregnant mothers [53].

When we dichotomized the years of publication into 2004 to 2010 and 2011 to 2019 , recently published studies (2011 to 2019) reported significantly lower pooled prevalence estimate of HBV-HIV co-infection, $2.252 \%$ ( $95 \% \mathrm{CI}=1.740$ to $3.765 \%$ ) in a sample of 45,185 (forty five thousand one hundred eighty five) pregnant women on antenatal care $(P<0.001)$ compared to earlier studies (2004-2010) with higher HBV-HIV pooled prevalence estimate of $6.356 \%$ in a sample of 2,929 (two thousand nine hundred twenty nine) pregnant women (95\% $\mathrm{CI}=3.611$ to $9.811 \%)$.

When we meta-analyzed data on whether the studies used HIV positive cohort or not to assess the prevalence of HBV-HIV co-infection among the pregnant mothers, interesting results were obtained. The lowest and highest HBV-HIV co-infection prevalence estimates of $1.661 \%$ (95\% CI $=0.542$ to $3.834 \%$ ) and $27.273 \%$ $(95 \% \mathrm{CI}=22.539$ to $32.420 \%)$ in a cohort of HIV positive

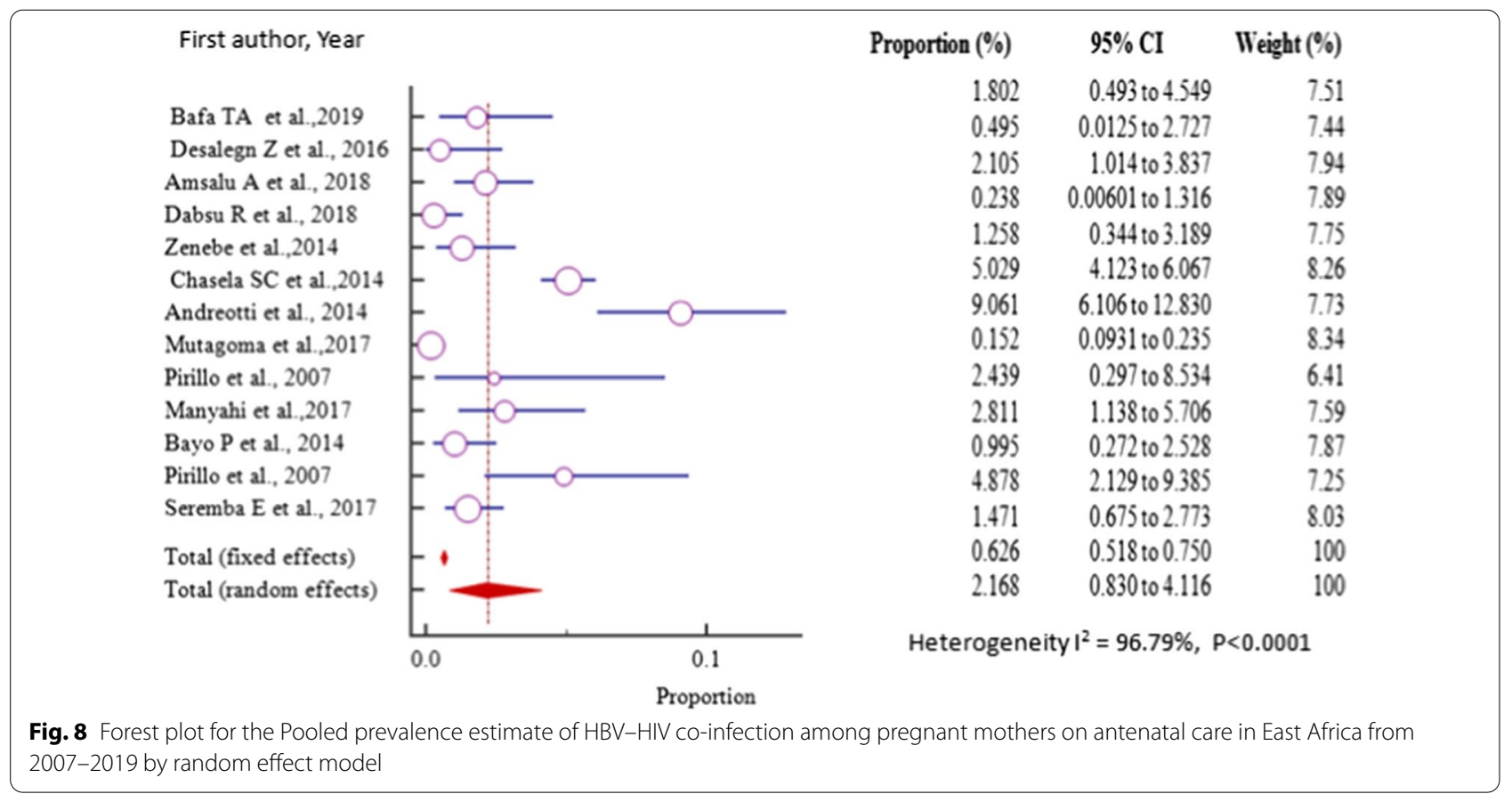




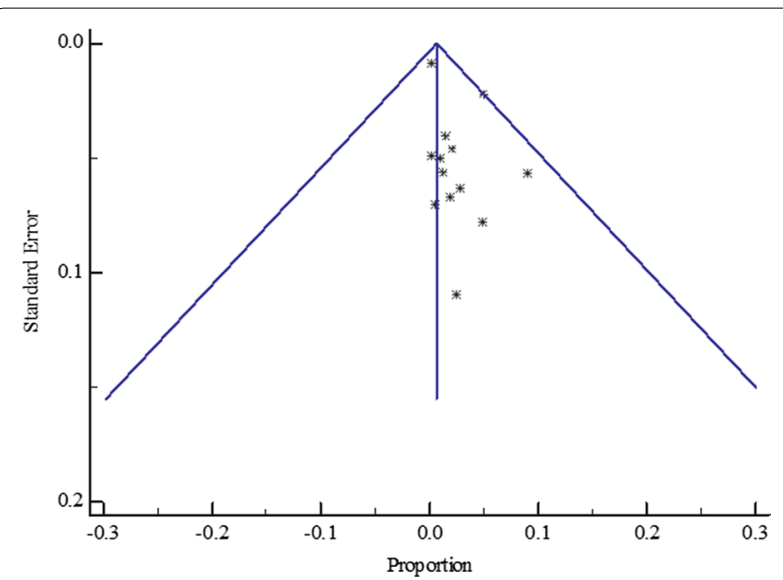

Fig. 9 Bias assessment funnel plot for HBV-HIV co-infection prevalence rate among pregnant mothers on antenatal care in East Africa 2007 to 2019 mothers were reported in Cameroon [55] and in Nigeria [53] respectively. On the other hand, the lowest and highest HBV-HIV co-infection prevalence of $0.032 \%$ (95\% $\mathrm{CI}=0.000810$ to $0.178 \%)$ and $12.174 \%(95 \% \mathrm{CI}=6.818$ to $19.582 \%)$ in the general population of mothers on antenatal care were found in studies reported from Ghana [42] and Burkina Faso [39] respectively. Whereas all the eligible studies included in our meta-analysis focused on HBV-HIV co-infection either in the general population or in HIV positive cohort pregnant mothers on antenatal care, one study [14] investigated the HBV-HIV co-infection both in the general population and among the HIV positive cohort. Indeed, the HIV positive pregnant mothers had a significantly higher HBV-HIV co-infection pooled prevalence of $8.312 \%$ ( $95 \% \mathrm{CI}=5.806$ to $11.220 \%$ ) in a sample of 9,332 (nine thousand three hundred thirtytwo) HIV positive cohort compared to the HBV-HIV co-infected mothers in the general population with a pooled prevalence estimate of $2.152 \%,(95 \% \mathrm{CI}=1.358$ to $3.125 \%)(P<0.001)$ in a sample of 39,388 (thirty-nine thousand three hundred eighty-eight) pregnant mothers. Finally, the prevalence of HBV-HIV co-infection prevalence in the separate studies appears not to have been confounded by the method used for the detection of the HBsAg since when we meta-analyzed data on the detection method of the HBsAg, the results did not differ significantly $(P>0.05)$.

\section{Risk factors for HBV-HIV co-infection}

Age, risk difference -0.517 ( $95 \% \mathrm{CI}=-0.942$ to -0.0916$)$ among 4 (four) studies, marital status, risk difference $0.432(95 \% \mathrm{CI}=0.177$ to 0.687$)$ within 6 (six) studies $\left(\mathrm{P}_{\text {het }}=0.0001\right)$ and employment, risk difference, 0.39 ( $95 \% \mathrm{CI}=0.0136$ to 0.775 ) among 5 (five) studies were independent risk factors significantly associated with HBV-HIV co-infection in pregnant mothers on ANC $(P<0.05)$ (Table 3, Figs. 12, 13, 14).

However, education level, risk difference $-0.289(95 \%$ $\mathrm{CI}=-0.764$ to 0.185$)$ among 6 (six) studies and level of

\section{Proportion (\%) $\quad 95 \% \mathrm{Cl} \quad$ Weight $(\%)$}

Random

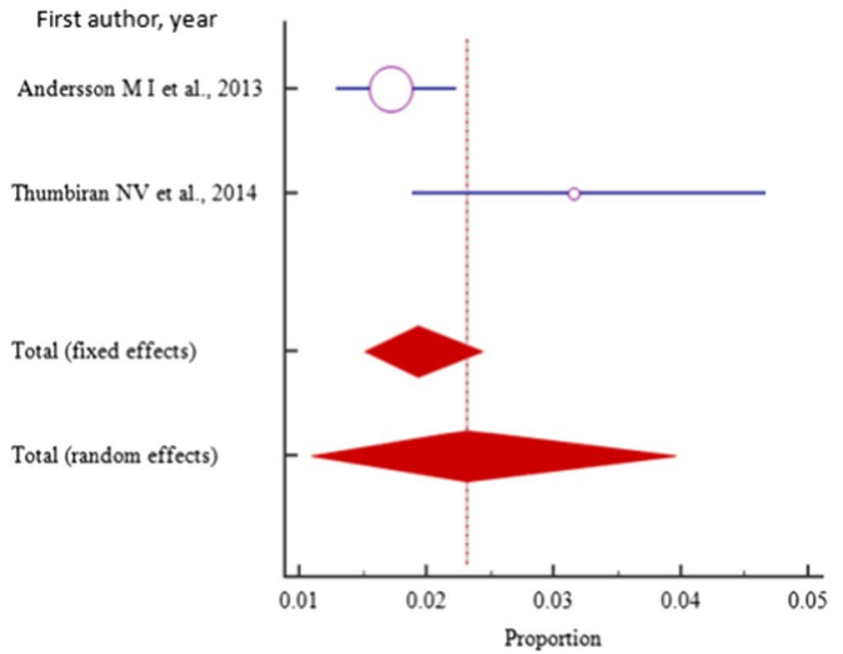

$1716 \quad 1288$ to $2238 \quad 57.43$

$3.158 \quad 1.882$ to $4.945 \quad 42.57$

$1.936 \quad 1.515$ to $2.437 \quad 100$

$2.317 \quad 1.105$ to $3.959 \quad 100$

Heterogeneity $\left(I^{2}\right)=78.40 \%, P=0.03141$

2012-2014 by random effects model 


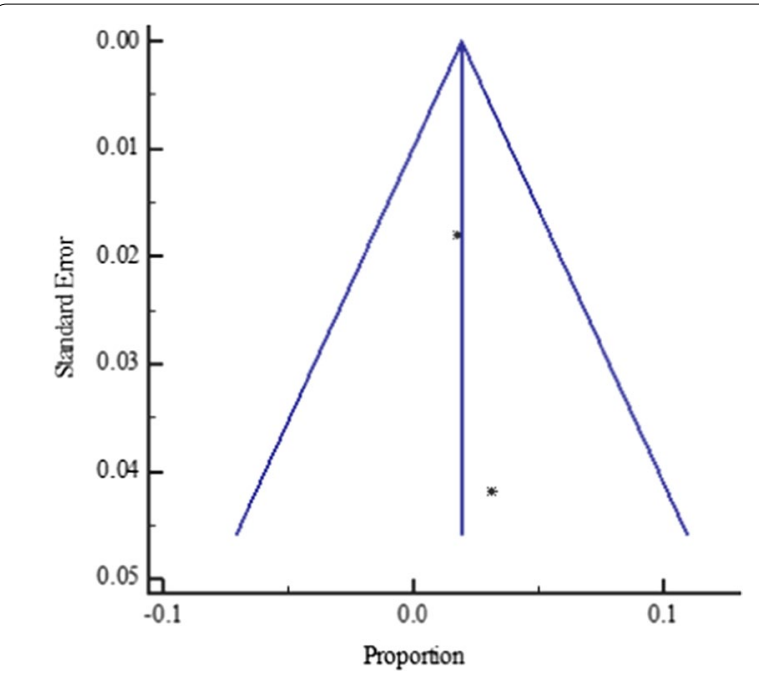

Fig. 11 Bias assessment funnel plot for HBV-HIV co-infection prevalence rate among pregnant mothers on antenatal care in South Africa 2013 to 2014 gravidity, risk difference $0.386(95 \% \mathrm{CI}=-1.007$ to 1.778$)$ among 2 (two) studies were not significantly associated with HBV-HIV co-infection in pregnant mothers on ANC $(P>0.05)$ (Table 3, Figs. 15, 16). Moreover, all the studies included in our meta-analysis for the synthesis of data on the risk factors associated with HBV-HIV coinfection among the pregnant women on ANC had high heterogeneities $\left(\mathrm{I}^{2}>81 \%, \mathrm{P}_{\text {het }} \geq 0.0001\right)$.

When we compared age, marital status, level of education, employment and magnitude of gravidity, with the prevalence of HBV-HIV co-infection among the pregnant mothers on $\mathrm{ANC}$, we again obtained interesting associations. The HBV-HIV co-infection was significantly higher in pregnant mothers aged 25 years and above $75.635 \%$ ( $95 \% \mathrm{CI}=52.956$ to $92.58 \%$ ), married pregnant mothers $68.94 \%(95 \% \mathrm{CI}=57.89$ to $83.689 \%)$ and among the employed mothers $70.756 \%$ $(95 \% \mathrm{CI}=47.657$ to $89.26 \%)(P<0.001)$. However, there was no significant association between magnitude of

Table 3 Risk factor meta-analysis for HBV-HIV co-infection pooled risk difference estimation among ANC attendees

\begin{tabular}{|c|c|c|c|c|c|c|}
\hline \multirow[t]{2}{*}{ Risk factor } & \multirow[t]{2}{*}{ No } & \multicolumn{5}{|l|}{ Analysis } \\
\hline & & Risk difference $(95 \% \mathrm{Cl})$ & $P$ value & Z score & $\mathrm{I}^{2}(\%)(95 \% \mathrm{Cl})$ & $P_{\text {het }}$ \\
\hline Age & 4 & $-0.517(-0.942$ to -0.0916$)$ & 0.017 & 2.382 & 91.44 (81.24 to 96.10$)$ & $<0.0001$ \\
\hline Marital status & 6 & 0.432 (0.177 to 0.687 ) & 0.01 & 3.321 & 81.57 (60.62 to 91.37) & $=0.0001$ \\
\hline Educ. level & 6 & $-.289(-0.764$ to 0.185$)$ & 0.232 & 1.192 & 95.65 (92.80 to 97.38) & $<0.0001$ \\
\hline Employment & 5 & 0.39 (0.0136 to 0.775$)$ & 0.042 & 2.030 & 92.90 (86.39 to 96.26$)$ & $<0.0001$ \\
\hline Gravidity & 2 & $0.386(-1.007$ to 1.778$)$ & 0.587 & 0.543 & 95.1 (85.33 to 98.36$)$ & $<0.0001$ \\
\hline
\end{tabular}

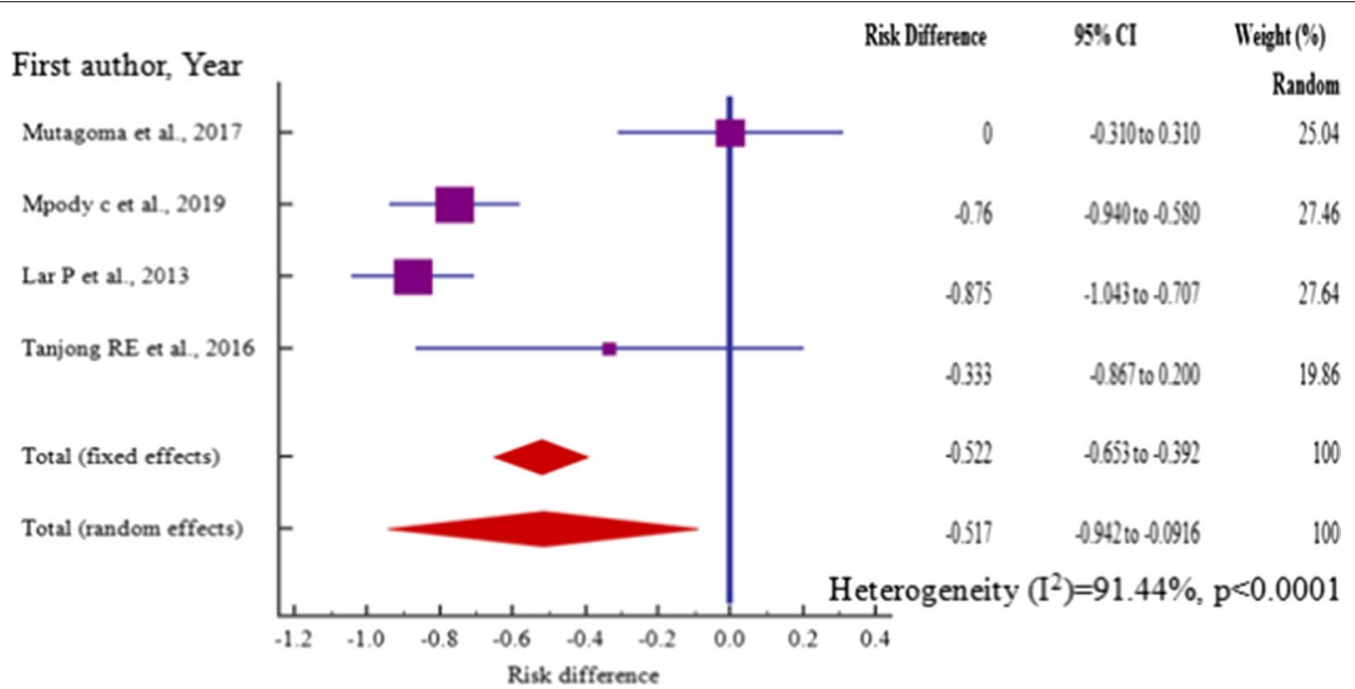

Fig. 12 Forest plot of risk difference for HBV-HIV co-infection for pregnant mothers attending antenatal care $<25$ years and $>25$ years from cross-section/cohort studies in sub-Saharan Africa from 2014 to 2019 


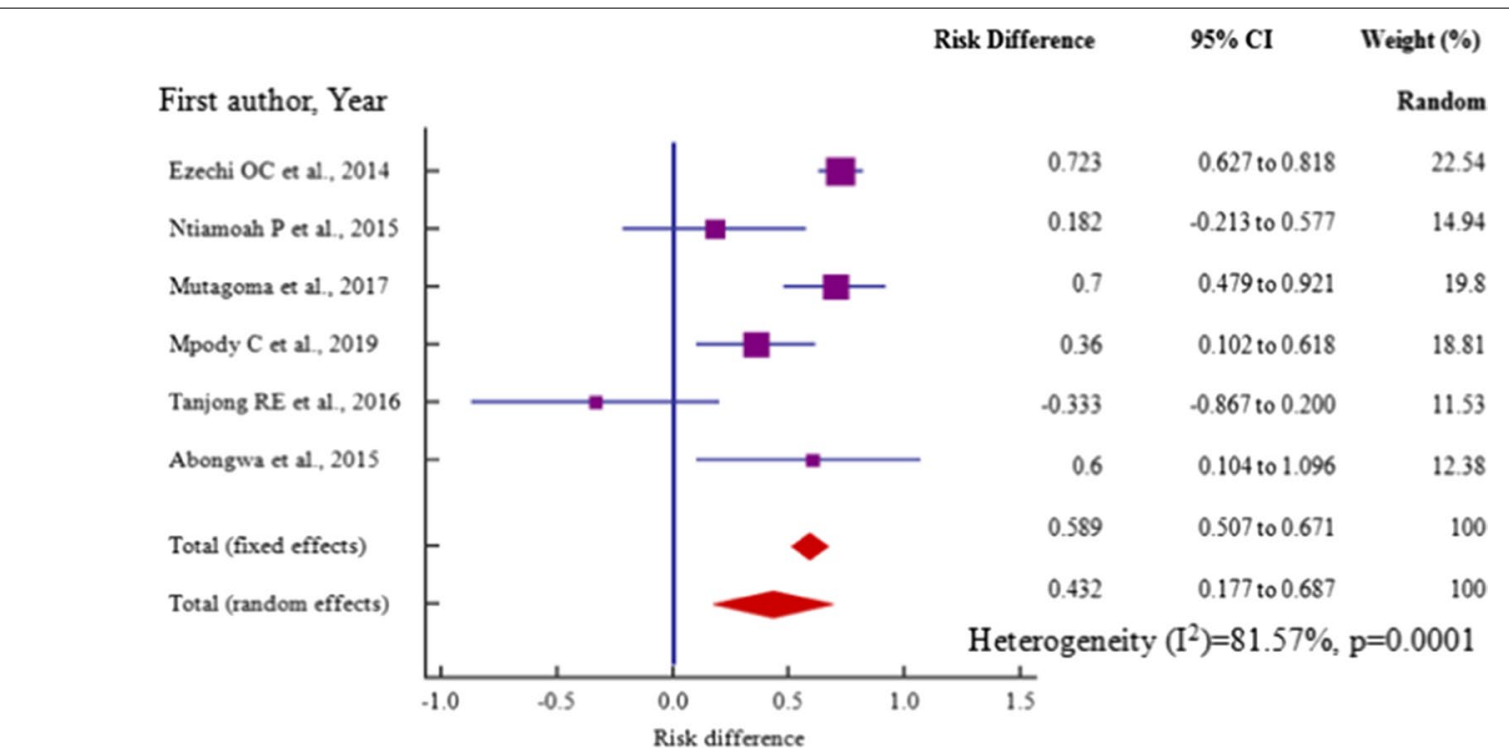

Fig. 13 Forest plot of risk difference for HBV-HIV co-infection among married and unmarried pregnant mothers from cross-section/cohort studies in sub-Saharan Africa from 2014 to 2019

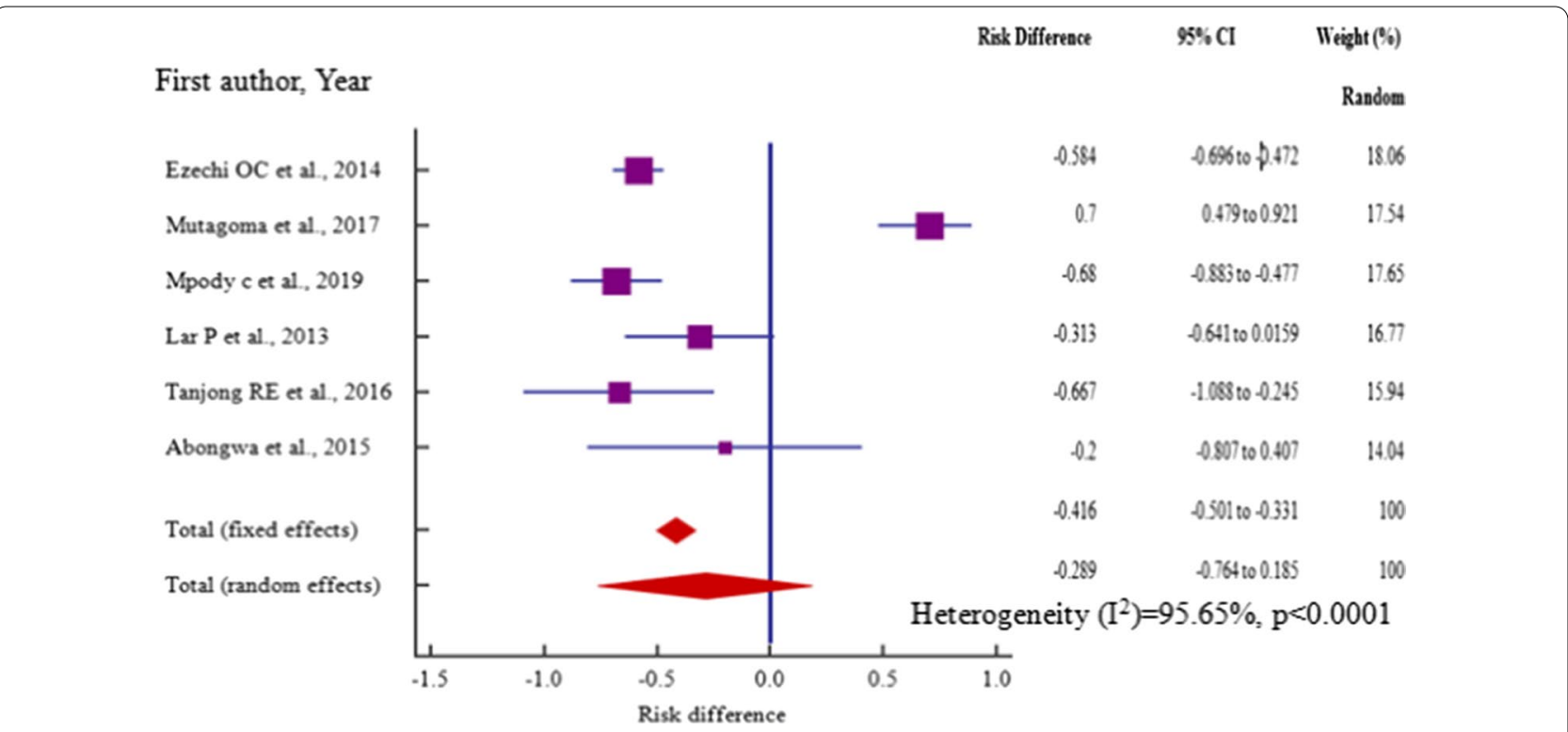

Fig. 14 Forest plot of risk difference for HBV-HIV co-infection among educated and uneducated pregnant mothers from cross-section/cohort studies in sub-Saharan Africa from 2014 to 2019

gravidity with the prevalence of HBV-HIV co-infection $(P=0.0546)$ (Table 4$)$. These observations are consistent with the increased risk of HBV-HIV co-infection among pregnant mothers in relation to age, marital status and employment record but not magnitude of gravidity as demonstrated by our meta-analysis of the risk difference (Table 3).

\section{Meta-regression}

Meta-regression analysis was performed to examine the continuous variables of sample size and prevalence HBV-HIV co-infection $(P=0.146)$ as well as year of publication $(P=0.560)$. The results were not significantly associated with HBV-HIV pooled prevalence $(P>0.05)$ (Fig. 17). 


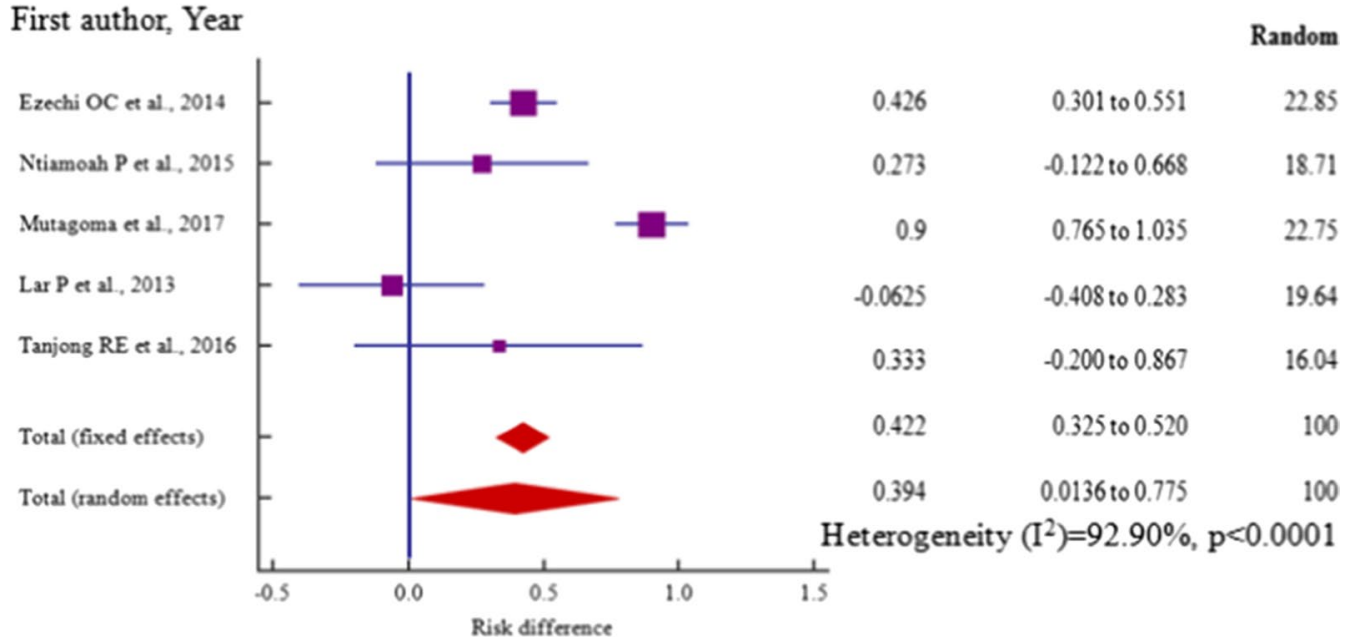

Fig. 15 Forest plot of risk difference for HBV-HIV co-infection among employed and unemployed pregnant mothers from cross-section/cohort studies in sub-Saharan Africa from 2014 to 2019

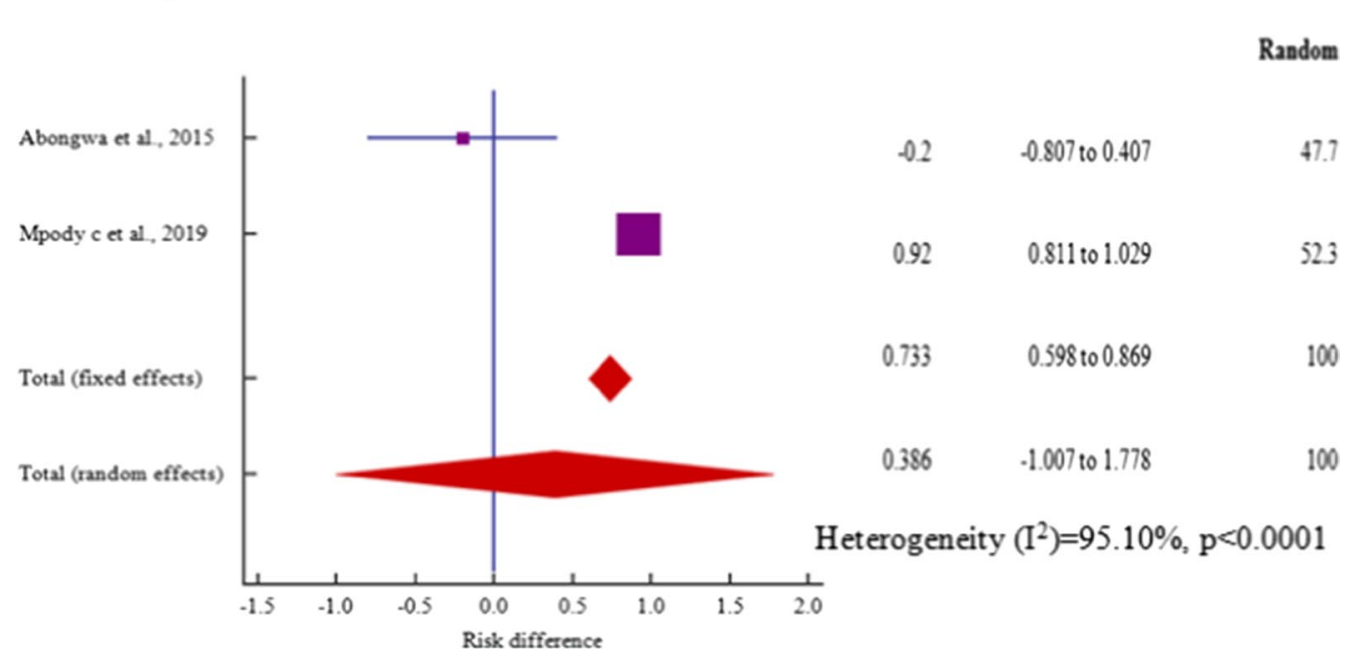

Fig. 16 Forest plot of risk difference for HBV-HIV co-infection among the primagradida and multigravida mothers from cross-section/cohort studies in sub-Saharan Africa from 2014 to 2019

\section{Sensitivity analysis}

We also performed a sensitivity analysis by removing one study with the largest sample size conducted in Rwanda [34]. For sensitivity analysis, the overall HBV-HIV pooled prevalence after omission, there was a slight increase to $3.444 \%$ ( $95 \% \mathrm{CI}=2.438$ to $4.616 \%)$ with heterogeneity $\mathrm{I}^{2}=96.58 \% \quad(95 \% \quad \mathrm{CI}=95.92 \quad$ to 97.13\%), $P<0.0001$ (Fig. 18).

\section{Discussion}

In our meta-analysis of 38 eligible studies, 36/38 (95\%) were cross-sectional and 2/38 (5\%) were from retrospective cohorts. Thus, the results of our study gave a reflection of HBV-HIV co-infection among pregnant women attending $\mathrm{ANC}$ at that point in time. The pooled prevalence estimate was $3.289 \%$ lower than the $4.9 \% \mathrm{HBV}-$ HIV co-infection prevalence reported in Europe [62] 
Table 4 Meta- analysis of the risk factors associated with HBV-HIV co-infection among pregnant mothers on ANC

\begin{tabular}{|c|c|c|c|c|}
\hline \multirow[t]{2}{*}{ Risk factor } & \multirow[t]{2}{*}{ Category } & \multirow[t]{2}{*}{ Number } & Analysis & $P$ value \\
\hline & & & \multicolumn{2}{|l|}{$\begin{array}{l}\text { Proportion \% } \\
(95 \% \mathrm{Cl})\end{array}$} \\
\hline \multicolumn{5}{|l|}{ Age } \\
\hline & $<25$ years & 4 & $\begin{array}{l}24.347(7.42 \text { to } \\
47.074)\end{array}$ & \\
\hline & $\geq 25$ years & 4 & $\begin{array}{l}75.635(52.956 \text { to } \\
92.58)\end{array}$ & $<0.001^{*}$ \\
\hline \multicolumn{5}{|l|}{ Marital status } \\
\hline & Married & 6 & $\begin{array}{l}68.94(57.89 \text { to } \\
83.689)\end{array}$ & \\
\hline & Unmarried & 6 & $\begin{array}{l}24.36(14.044 \text { to } \\
36.456)\end{array}$ & $<0.001^{*}$ \\
\hline \multicolumn{5}{|c|}{ Level of education } \\
\hline & Below secondary & 6 & $\begin{array}{l}35.52(15.73 \text { to } \\
58.345)\end{array}$ & \\
\hline & $\begin{array}{l}\text { Secondary \& } \\
\text { above }\end{array}$ & 6 & $\begin{array}{l}63.458(40.44 \text { to } \\
83.617)\end{array}$ & $<0.001^{*}$ \\
\hline \multicolumn{5}{|l|}{ Employment } \\
\hline & Employed & 5 & $\begin{array}{l}70.756 \text { (47.657 to } \\
89.26)\end{array}$ & \\
\hline & Unemployed & 5 & $\begin{array}{l}25.193(9.212 \text { to } \\
45.792)\end{array}$ & $<0.001^{*}$ \\
\hline \multirow[t]{2}{*}{ Gravidity } & Primagravida & 2 & $\begin{array}{l}25.504 \text { ( } 0.757 \text { to } \\
83.0)\end{array}$ & \\
\hline & Multigravida & 2 & $\begin{array}{l}74.496(16.99 \text { to } \\
99.243)\end{array}$ & 0.0546 \\
\hline
\end{tabular}

* $P$ value $<0.05$ is considered statistically significant

among HIV positive pregnant women attending ANC and $4.6 \%$ reported in India among the 689 HIV infected pregnant women [63]. However, although the HBV-HIV co-infection prevalencies reported from Europe and India among the HIV positive cohort were lower than the prevalence of $8.321 \%$ in our meta-analysis in a similar cohort, the prevalence of HBV-HIV co-infection (8.7\%) in Europe among HIV positive pregnant mothers with African decency [62] was in fair conformity with the result of our meta-analysis for the HIV positive cohort.

Results synthesized from studies that sampled mothers from the general population had generally lower HBVHIV co-infection prevalence (2.152\%) although relatively higher than the mean HBV-HIV co-infection prevalence reported in India (1.09\%) from 36,379 pregnant women attending antenatal care from 15 antenatal care clinics [64], Iran (0.0\%) among pregnant women [65], in Turkey (0.0004\%) among 60,562 pregnant women [66], Turkey (0.1\%) among 2548 pregnant women [67] and Cambodia (1.0\%) [93]

The wide variation in prevalence of HBV-HIV coinfection among the pregnant mothers from SSA countries, Asia and Europe can be attributed to differences in implementation of control strategies, vaccination coverage [68], differences in endemicity of both HIV and HBV [1-4, 69], behavioral and cultural practices and differences in the sensitivity of the diagnostic methods employed [70]. Most importantly however, host genetic factors $[71,72,85]$ and the infecting genotypes $[15,73-$ 76] could be more influential factors in the risk of infection to HBV creating differences and similarities in the burden of HBV-HIV co-infection over a wide ethnic and geographical divide. Among the host genetic factors, polymorphisms in the cytokine promoter gene [94, 95] Vitamin D Receptor $[96,97]$ and Human Leucocyte Antigen $[98,99]$ influence the susceptibility to viral infections yet these are individual and population specific [94-99].
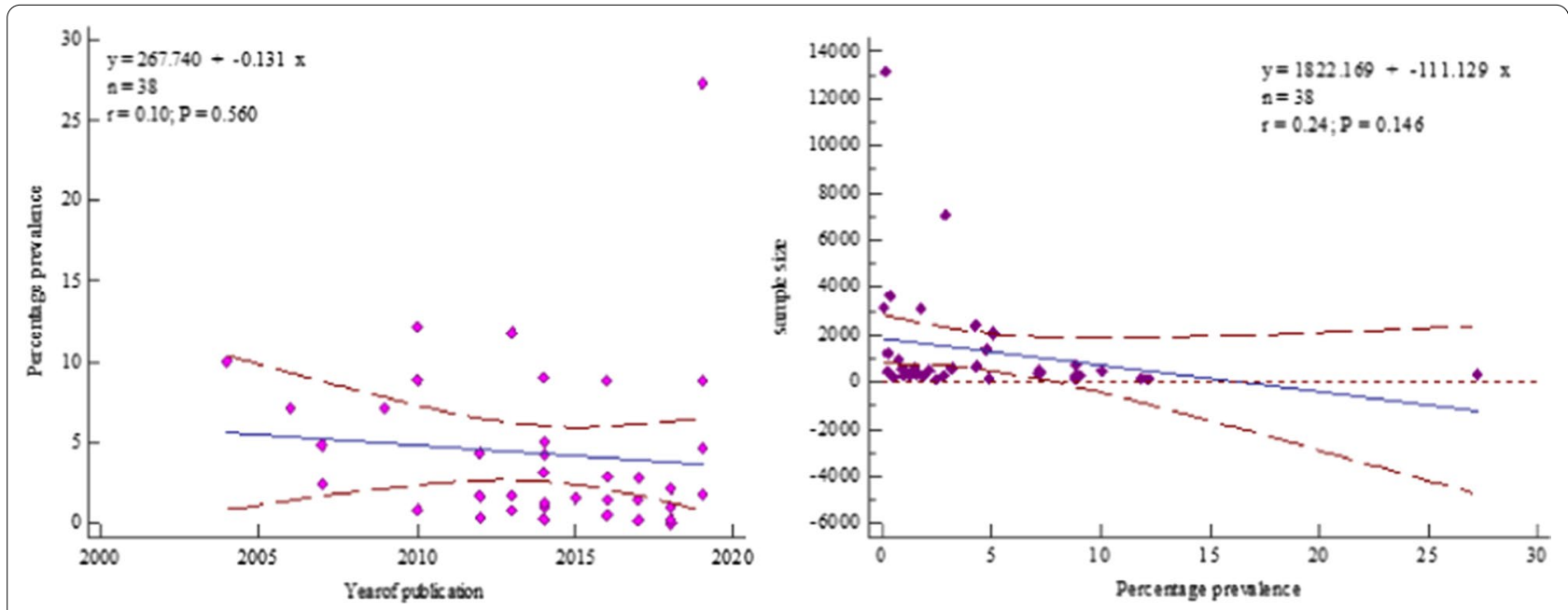

Fig. 17 Meta-regression analysis by sample size and year of publication 


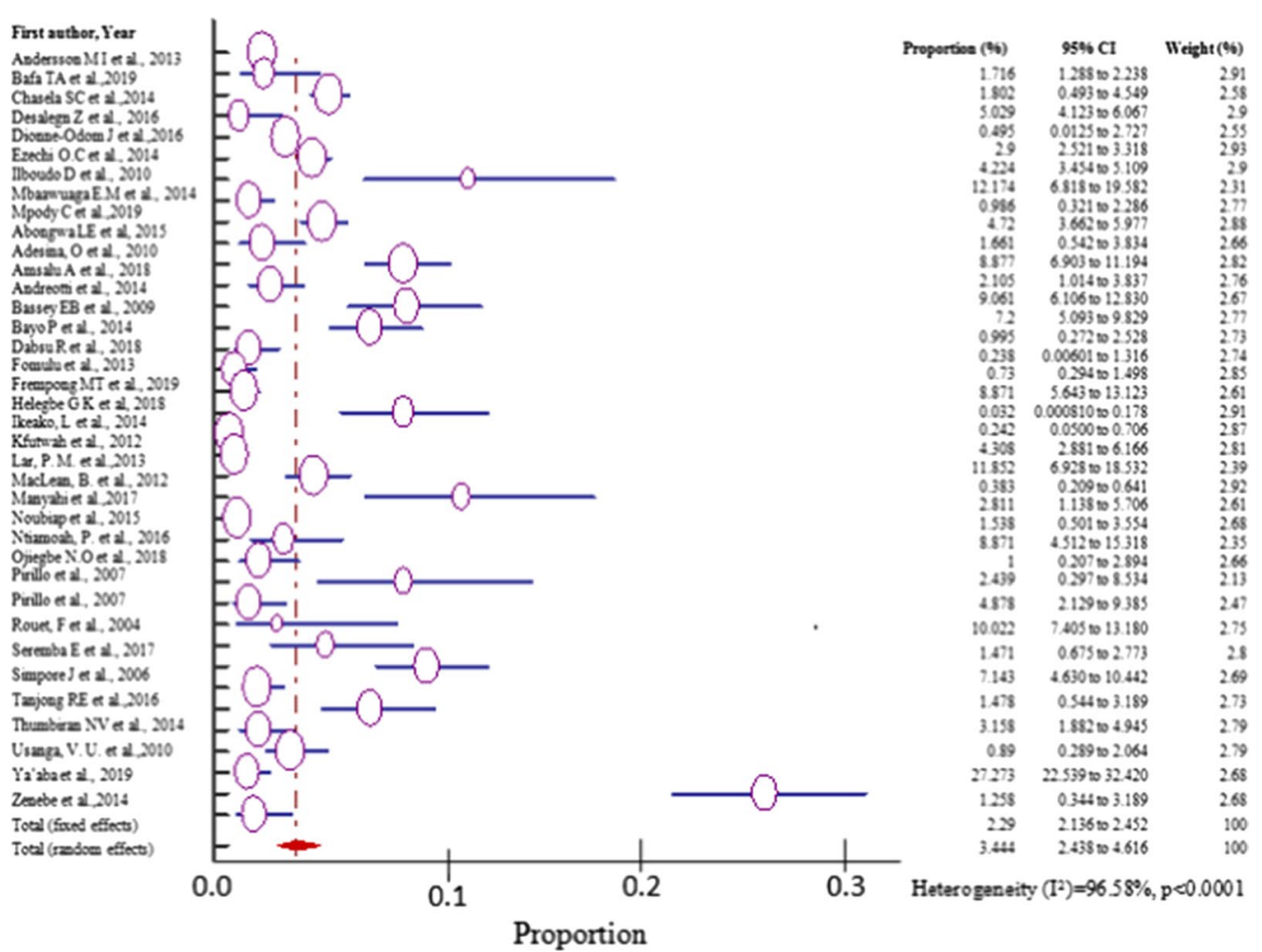

Fig. 18 Sensitivity analysis after omission of the study with the largest sample size by the random effect model

Similarly, available evidence has implicated genotype A to be the most prevalent in HBV-HIV co-infection [77]. Moreover, epidemiological studies on HBV disease profile have shown that infection with genotype A is pandemic [78] and predominant in most of the sub-Saharan African countries [79]. Consequently, the similarity in the observed burden of HBV-HIV co-infection among pregnant mothers from one region to another could be attributed to the universal geographical distribution of $\mathrm{HBV}$ genotype A.

The pooled prevalence of HBV-HIV co-infection estimate was highest in West Africa (5.155\%) followed by Central Africa (2.441\%), South Africa (2.317\%) and least in East Africa (2.168\%). The high burden of HBVHIV co-infection among the pregnant women in West Africa can partly be explained by the target population used in many West African studies included in our meta-analysis. Out of the 12 studies that targeted HIV positive mothers, five $(5 / 12)$ were conducted from West Africa (42\%) and only 3/12 (25\%) for each of Central Africa and East African countries. Moreover, 3/7 eligible studies (43\%) included in our meta-analysis from Central Africa targeted HIV positive pregnant mothers but only 3/13 (23.1\%) from East African countries. The shared route of transmission for both viruses [80] and the compromised immunity due to HIV infection partly explains the high burden of HBV-HIV co-infection among the HIV positive mothers. Most importantly, the global highest burden of HBV-HIV co-infection has been reported from Western African countries $[81,82]$. The pooled prevalence estimate of HBV-HIV co-infection among the pregnant mothers in South Africa reported in our meta-analysis should be interpreted with caution since only two eligible studies were included in our meta-analysis [14, 54]. Consequently, we were limited in our ability to make a comprehensive regional comparison of HBV-HIV co-infections among the pregnant mothers on ANC. For example, in southern sub-Saharan Africa where estimated HIV prevalencies are higher than rest of the continent with majority of the countries having a prevalence $\geq 20 \%$ [100], only one country had data on the HBV-HIV co-infection among pregnant mothers [14, 54]. On the other hand, western sub-Saharan Africa with apparently low HIV prevalence in the general population posted the highest HBV-HIV co-infection prevalence among the pregnant women $[18,39-53]$. This can be attributed to differential HIV burden in this region by sex with women having almost twice as high HIV prevalence than men [101]. Moreover, women continue to carry a higher 
HIV burden in SSA [102] accounting for 58\% of the people living with HIV (PLWH) in our region [103].

The differences in regional burden of HBV-HIV coinfection among the pregnant mothers can in addition be explained by differences in endemicity of the viruses [69], circulating genotypes [83], risk factors to infection [84], host genetic factors [85], vaccination coverage [68] as well as implementation of control and prevention strategies [86]. However, the HBsAg detection method did not confound the results of our meta-analysis $(P>0.05)$.

Regarding the year of publication, recently published studies reported significantly lower pooled prevalence estimate of $2.252 \%$ compared to earlier studies with pooled prevalence of $6.386 \%(P<0.001)$. The decrease in HBsAg positivity rate among pregnant women on ANC observed in recent publications in our meta-analysis has also been reported in Turkey from a period of 2013 to 2016 [87] and from 1995 to 2015 [88]. This could be probably attributed to improved awareness of both viruses [68] as well as introduction of national immunization programs.

Age, marital status, level of education and employment were significantly associated with HIV-HBV co-infection among pregnant women in our meta-analysis $(P<0.001)$. Therefore, interventions to manage co-infections with HBV and HIV among pregnant mothers should target those who are married, employed, educated and aged between $25-30$ years. This is in conformity with the findings by Mohammad et al. [89], who reported that, the marital status, occupation and age were significant risk factors for HIV-HBV co-infections among HIV-infected patients in Iran. Similarly, a study on HBV-HIV coinfected pregnant women in Europe reported a significant association of age with HBV-HIV co-infection with women aged 25-29 years being at higher risk of HBVHIV co-infection [62] in conformity with our meta-analysis. The high sexual activity in the age group $\geq 25$ years [90] has been implicated in the high prevalence of HBV-HIV co-infection since both HBV and HIV are sexually transmitted infections [91]. Perhaps, there is also an unmet need pertaining being faithful to each partner in marriages and among those in sexual relationships increasing the risk of transmitting both HIV and HBV in sub-Saharan African in general and pregnant women in particular. Most importantly however, despite the recommendation for administration of $\mathrm{HBV}$ vaccine to all infants in 1991 by the Advisory Committee on Immunization (ACIP) in the United States [104], the implementation of the HBV vaccination program as part of the extended program on immunization (EPI) in Africa started in 1995 [105]. Thus pregnant mothers born before 1995 were not immunized against HBV in most of the SSA countries increasing the burden of HBV-HIV co-infection in those above 25 years as opposed to those below 25 years who were born after 1995.

Whereas gravidity was not statistically associated with significant risk of getting HIV-HBV co-infection $(P=0.0546)$ in our meta-analysis, having two or more pregnancies was identified as risk factor associated with HBV and HIV co-infection in the study on HBV infections among pregnant women in Arab countries [92].

\section{Conclusion}

This meta-analysis has provided up-to-date information on the HBV-HIV co-infection status among pregnant mothers on antenatal care in sub-Saharan Africa. Moreover, most of the studies are recently published (2011to 2019). Our meta-analysis has identified differences in burden of the co-infection with both viruses from different sub-regions. We have also highlighted the risk factors to HBV-HIV co-infection among pregnant mothers in sub-Saharan. The overall pooled prevalence was higher than prevalencies reported in Europe and Asia suggesting an unmet need for effective control strategies increasing the risk of having a pool of new born with HBV and perhaps HIV. However, HBV-HIV co-infection among pregnant mothers in HIV positive cohort subgroup pooled prevalence estimate in our meta-analysis is comparable to those reported in previous studies due to the shared route of transmission for both viruses and the discrepancies are due to differences in endemicity, control strategies, infecting genotypes and host immunity. We recommend that HBV screening be prioritized during antenatal visits as is the case with HIV in sub-Saharan Africa because of the observed burden among the HIV positive mothers in our meta-analysis.

\section{Limitations}

Published literature in peer reviewed journals on HBVHIV co-infection among pregnant mothers attending antenatal care is scanty. The 38 eligible studies included in our meta-analysis were conducted from only 13 SSA countries. Therefore, the HBV-HIV co-infection pooled prevalence estimate among pregnant mothers of 3.3\% may not be representative of the burden of the co-infection in SSA countries. Moreover, HBV screening in many SSA countries is not routine and therefore its epidemiology is not well documented.

\footnotetext{
Abbreviations

SSA: Sub-Saharan Africa; HIV: Human immunodeficiency virus; HBV: Hepatitis $B$ virus; ANC: Antenatal care; PRISMA: Prefered reporting items for systematic reviews and meta-analyses; HBeAg: Hepatitis B pre-core Antigen; HBCAg: Hepatitis B core antigen; HBsAg: Hepatitis B surface antigen; CART: Combined antiretroviral therapy; MTCT: Mother-to-child-transmission; CD: Cluster of differentiation; AAS: Abbott ARCHITECT system; VCIA: Vitros chemiluminescence
} 
immunoassay; EIA: Enzyme immuno assay; ELISA: Enzyme linked immuno assay; RDT: Rapid diagnostic test; QS: Quality score.

\section{Acknowledgements}

We are grateful to ICT system management at Islamic University in UgandaKampala Campus for allowing us to access the data base. We also thank Dr. Ntanda K Moses, Makerere University College of Computing and Information Sciences for the ICT technical support.

\section{Authors' contributions}

HMK is a molecular immunologist and virologist working on molecular immunology during hepatitis B virus infection targeting an African population. DN is an immunologist and biochemist with a PhD in Biochemistry and immunology working in the department of Plant Sciences, Microbiology and Biotechnology, College of Natural Sciences, Makerere University. HS holds a $\mathrm{PhD}$ in Biochemistry \& is a physician in the Department of Microbiology Mak erere University working on molecular markers of drug resistance in HIV and malaria infections. $\mathrm{PO}$ is a physician with a $\mathrm{PhD}$ in gastroenterology and is an associate professor of gastroenterology with a lot of expertise in liver diseases working in the department of Medicine College of Health Sciences, Makerere University. AW is a microbiologist and immunologist working on anti-microbial resistance. HMK and AW are both Ph.D. students at Makerere University in the colleges of Health Sciences and Natural Sciences respectively employed at Islamic University in Uganda in the Department of Medical Microbiology as Doctoral fellows. All authors read and approved the final manuscript.

\section{Funding}

The authors declare that they did not receive any specific funding for the study.

\section{Availability of data and materials}

All data generated or analyzed during this study are included in this published article.

\section{Ethics approval and consent to participate}

Not applicable.

\section{Consent for publication}

Not applicable.

\section{Competing interests}

The authors declare that they have no competing interests.

\section{Author details}

${ }^{1}$ Department of Medical Microbiology, College of Health Sciences, Makerere University, P.O Box 7062, Kampala, Uganda. ${ }^{2}$ Department of Medical Microbiology, Habib Medical School, Faculty of Health Sciences, Islamic University in Uganda, P.O Box 7689, Kampala, Uganda. ${ }^{3}$ Department of Plant Sciences, Microbiology and Biotechnology, College of Natural Sciences, Makerere University, P.O Box 7062, Kampala, Uganda. ${ }^{4}$ Department of Medicine, College of Health Sciences, Makerere University, P.O Box 7062, Kampala, Uganda.

Received: 19 August 2020 Accepted: 27 October 2020

Published online: 07 November 2020

\section{References}

1. Lemoine M, Nayagam S, Thursz M. Viral hepatitis in resource-limited countries and access to antiviral therapies: current and future challenges. Futur Virol. 2013;8(4):371-80.

2. Wang H, Wolock T, Carter A, Nguyen G, Kyu H, Gakidou E, Hay S, Mills E, Trickey A, Msemburi W, Coates M, Mooney M. Estimates of global, regional, and national incidence, prevalence, and mortality of HIV, 1980-2015: the Global Burden of Disease Study 2015. Lancet HIV. 2016;3(8):e361-87.

3. World Health Organization. Global hepatitis report. 2017.

4. UNAIDS. Global AIDS update, . Report. Geneva: UNAIDS; 2016. p. 2016.

5. Platt L, Easterbrook P, Gower E, McDonald B, Sabin K, McGowan C, Yanny I, Razavi H, Vickerman, . Prevalence and burden of HCV co-infection in people living with HIV: a global systematic review and meta-analysis. P Lancet Infect Dis. 2016;16(7):797-808.

6. Thio CL. Hepatitis B, and human immunodeficiency virus co-infection. Hepatology. 2009;49(5 Suppl):S138-45

7. Mave V, Kadam D, Kinikar A, Gupte N, Bhattacharya D, Bharadwaj R, Thio C. Impact of maternal hepatitis B virus coinfection on mother-to-child transmission of HIV. HIV Med. 2014;15(6):347-54.

8. Sun HY, Sheng WH, Tsai MS, Lee KY, Chang SY, Hung CC. Hepatitis B virus coinfection in human immunodeficiency virus-infected patients: a review. World J Gastroenterol. 2014;20(40):14598-614.

9. Safir A, Levy A, Sikuler E, Sheiner E. (2010) Maternal hepatitis B virus or hepatitis $C$ virus carrier status as an independent risk factor for adverse perinatal outcome. Liver Int. 2010;30(5):765-70.

10. To W, Cheung W, Mok K. Hepatitis B surface antigen carrier status and its correlation to gestational hypertension. Aust N Z J Obstet Gynaecol. 2003:43:110-22.

11. Chang JJ, Wightman F, Bartholomeusz A, Ayres A, Kent SJ, Sasadeusz $J$, Lewin SR. Reduced hepatitis B virus (HBV)-specific CD4+ T-cell responses in human immunodeficiency virus type 1-HBV-coinfected individuals receiving HBV-active antiretroviral therapy. J Virol. 2005;79:3038-51.

12. Lacombe K, Bottero J, Lemoine M, Boyd A, Girard PM. HIV/hepatitis B virus co-infection: current challenges and new strategies. J Antimicrob Chemother. 2010;65:10-7.

13. Iser DM, Lewin RS. The pathogenesis of liver disease in the setting of HIV-hepatitis B virus co-infection. Antiviral Therapy. 2008;14:155-64

14. Andersson MI, Maponga TG, ljaz S, Barnes J, Theron GB, Meredith SA, Preiser W, Tedder RS. The epidemiology of hepatitis B virus infection in HIV-infected and HIV-uninfected pregnant women in the Western Cape, South Africa. Vaccine. 2013;31(47):5579-84.

15. Zhang S, Li R, Wang Y, Liu Q, Zhou Y, Hu Y. Seroprevalence of hepatitis B surface antigen among pregnant women in Jiangsu, China, 17 years after introduction of hepatitis B vaccine. Int J Gynaecol Obstet. 2010;109:194-7.

16. Zhang Q, Cao G. Genotypes, mutations and viral load of hepatitis $B$ virus and the risk of hepatocellular carcinoma. Hepatitis Monthly. 2011;11(2):86-91.

17. Wasmuth JC. HepatitisB-epidemiology, transmission and natural history. In: Mauss S, Berg T, Rockstroh J, Sarrazin C, Wedemeyer H, editors. Hepatology. Dusseldorf: Flying Publisher; 2009, p: 25-36.

18. Lar PM, Pam VK, Christopher PB, Gwamzhi L, Mawak JD. Prevalence and immune status of HIV/HBV co-infected pregnant women. Afr J Clin Exp Microbiol. 2013;14(3):120-6

19. National Institute for Health and Clinical Excellence (NICE) Ante-natal Care. 2008. Routine care for healthy pregnant women. National Collaborating Center for Women's and Children's Health: 62:1"454.

20. American College of Obstetricians and Gynecologists (ACOG) ACOG Practice Bulletin (2007). 86. ACOG, Washington DC: Viral Hepatitis in Pregnancy.

21. Umutesi J, Simmons B, Makuza JD, Dushimiyimana D, Mbituyumuremyi A, Uwimana JM, Nsanzimana S. Prevalence of hepatitis B and C infection in persons living with HIV enrolled in care in Rwanda. BMC Infect Dis. 2017;17(1):315.

22. United Nations (UN) Country classification (2014) available at https:// www.un.org/en/development/desa/policy/wesp/wesp_current/2014w esp_country_classification.pdf

23. Stang A. Critical evaluation of the Newcastle-Ottawa scale for the assesment of the quality of non-randomised studies in meta-analysis of genome searches. Genet Epidemiol. 2010;25:603-5.

24. Zintzaras E, loannidis JP. Heterogeneity testing in meta-analysis of genome searches. Genet Epidemiol. 2005;28:123-37.

25. DerSimonian $\mathrm{R}$, Kacker R. Random-effects model for meta-analysis of clinical trials: an update. Contemp Clin Trials. 2007;28:105-14.

26. Neyeloff JL, Fuchs CS, Moreira BL. 2012. Meta-analyses and forest plots using a microsoft excel spreadsheet: step-by-step guide focusing on descriptive data analysis. BMC Res Notes 5:52

27. Bafa TA, Egata AD. Sero-epidemiological patterns and predictors of hepatitis B, C and HIV viruses among pregnant women attending antenatal care clinic of Atat Hospital Southern Ethiopia. SAGE Open Med. 2020:8:2050312119900870. 
28. Desalegn Z, Mihret A, Beyene HB, Yilma M, Seid Y, Tamiru W, Ebstie YA. Survey of hepatitis $B$ virus infection and risk factors among pregnant women at public hospital in Ethiopia. Int J Biomed Res. 2016;7(7):450-6.

29. Amsalu, A., Ferede, G., Eshetie, S., Tadewos, A., \& Assegu, D. Prevalence, infectivity, and associated risk factors of hepatitis B virus among pregnant women in Yirgalem hospital, Ethiopia: Implication of Screening to Control Mother-to-Child Transmission. J Pregnancy 2018.

30. Dabsu R, Ejeta E. Seroepidemiology of hepatitis B and C virus infections among pregnant women attending antenatal Clinic in Selected Health Facilities in east Wollega zone, West Oromia, Ethiopia. BioMed Research International.

31. Zenebe Y, Mulu W, Yimer M, Abera B. Sero-prevalence and risk factors of hepatitis $B$ virus and human immunodeficiency virus infection among pregnant women in Bahir Dar city, Northwest Ethiopia: a cross sectional study. BMC Infect Dis. 2014;14(1):118

32. Chasela CS, Kourtis AP, Wall P, Drobeniuc J, King CC, Thai H, Jamieson DJ. Hepatitis B virus infection among HIV-infected pregnant women in Malawi and transmission to infants. J Hepatol. 2014;60(3):508-14

33. Andreotti M, Pirillo MF, Liotta G, Jere H, Maulidi M, Sagno JB, Marazzi $M C$. The impact of HBV or HCV infection in a cohort of HIV-infected pregnant women receiving a nevirapine-based antiretroviral regimen in Malawi. BMC Infect Dis. 2014;14(1):180.

34. Mutagoma M, Balisanga H, Malamba SS, Sebuhoro D, Remera E, Riede DJ, Nsanzimana S. Hepatitis B virus and HIV co-infection among pregnant women in Rwanda. BMC Infect Dis. 2017;17(1):1-7.

35. Pirillo MF, Bassani L, Germinario EA, Mancini MG, Vyankandondera J, Okong P, Giuliano M. Seroprevalence of hepatitis B and C viruses among HIV-infected pregnant women in Uganda and Rwanda. J Med Virol. 2007;79(12):1797-801.

36. Manyahi J, Msigwa Y, Mhimbira F, Majigo M. High sero-prevalence of hepatitis B virus and human immunodeficiency virus infections among pregnant women attending antenatal clinic at Temeke municipal health facilities, Dar es Salaam, Tanzania: a cross sectional study. BMC Pregnancy Childbirth. 2017;17(1):109. https://doi.org/10.1186/s1288 4-017-1299-3.

37. Bayo, P., Ochola, E., Oleo, C., \& Mwaka, A. D. (2014). High prevalence of hepatitis $B$ virus infection among pregnant women attending antenatal care: a cross-sectional study in two hospitals in northern Uganda. BMJ Open 4(11)

38. Seremba E, Van Geertruyden JP, Ssenyonga R, Opio CK, Kaducu JM, Sempa JB, Ocama P. Early childhood transmission of hepatitis B prior to the first hepatitis $B$ vaccine dose is rare among babies born to HIV-infected and non-HIV infected mothers in Gulu, Uganda. Vaccine. 2017;35(22):2937-42.

39. Ilboudo D, Simpore J, Ouermi D, Bisseye C, Sagna T, Odolini S, Nikiema JB. Towards the complete eradication of mother-to-child HIV/HBV coinfection at Saint Camille Medical Centre in Burkina Faso, Africa. Braz J Infect Dis . 2010;14(3):219-24.

40. Simpore J, Savadogo A, Ilboudo D, Nadambega MC, Esposito M, Yara J, Musumeci S. Toxoplasma gondii, HCV, and HBV seroprevalence and co-infection among HIV-positive and-negative pregnant women in Burkina Faso. J Med Virol. 2006;78(6):730-3

41. Frempong MT, Ntiamoah P, Annani-Akollor ME, Owiredu WK, AddaiMensah O, Owiredu EW, Sallah L. Hepatitis B and C infections in HIV-1 and non-HIV infected pregnant women in the Brong-Ahafo Region, Ghana. PloS one. 2019;14(7):e0219922.

42. Helegbe GK, Aryee PA, Mohammed BS, Wemakor A, Kolbila D, Abubakari AW, Ofosu E. Seroprevalence of malaria and hepatitis B coinfection among pregnant women in tamale metropolis of Ghana: a crosssectional study. The Canadian journal of infectious diseases \& medical microbiology= Journal canadien des maladies infectieuses et de la microbiologie medicale.

43. Ntiamoah P. The prevalence of Hepatitis B and/or Hepatitis C virus (HBV and/or HCV) co-infection among HIV-infected pregnant women (Doctoral dissertation)

44. Rouet F, Chaix ML, Inwoley A, Msellati P, Viho I, Combe P, ANRS 1236 DITRAME-B\&C Study Group. 2004. HBV and HCV prevalence and viraemia in HIV-positive and HIV-negative pregnant women in Abidjan, Côte d'Ivoire: The ANRS 1236 study. J Med Virol. 74(1), 34-40.

45. MacLean, B., Hess, R. F., Bonvillain, E., Kamate, J., Dao, D., Cosimano, A., $\&$ Hoy, S. (2012). Sero-prevalence of hepatitis B surface antigen among pregnant women attending the Hospital for Women \& Children in Koutiala, Mali. South Afr Med J. 102(1).

46. Ezechi OC, Kalejaiye OO, Gab-Okafor CV, Oladele DA, Oke BO, Musa ZA, Ezeobi PM. 2014. Sero-prevalence and factors associated with Hepatitis $\mathrm{B}$ and $\mathrm{C}$ co-infection in pregnant Nigerian women living with HIV Infection. Pan Afr Med J. 17(1).

47. Mbaawuaga EM, Iroegbu CU, Ike AC, Jombo GTA. Studies on prevalence, co-infection and associated risk factors of hepatitis B virus (HBV) and Human immunodeficiency virus (HIV) in Benue State, Nigeria. Sci J Public Health. 2014;2(6):569-76.

48. Adesina O, Oladokun A, Akinyemi O, Adedokun B, Awolude O, Odaibo G, Olaleye D, Adewole I. Human immuno-deficiency virus and hepatitis $B$ virus coinfection in pregnancy at the University College Hospital, Ibadan. Afr J Med Med Sci. 2010;39(4):305-10.

49. Bassey EB, Moses AE, Udo SM, Umo AN. 2009 Parallel and overlapping human immunodeficiency virus, hepatitis $B$ and $C$ virus infections among pregnant women in the federal capital territory, Abuja, Nigeria. Online J Health Allied Sci. 8(1)

50. Ikeako LC, Ezegwui HU, Ajah LO, Dim CC, Okeke TC. Seroprevalence of Human Immunodeficiency Virus, Hepatitis B, Hepatitis C, syphilis, and co infections among antenatal women in a tertiary institution in south east, Nigeria. Ann Med Health Sci Res. 2014;4(6):954-8.

51. Ojiegbe NO, Eleje GU, Nduka EC, Ikechukwu E, Okaforcha AOI. Hepatitis $B$ virus infection and infectivity status among pregnant women in Nigeria. Hong Kong J Obstetrics Gynaecol. 2018;1(1):06-13.

52. Usanga VU, Abia-Bassey I, Udoh SM, Ani F, Archibong E. The Seroprevalence of Hepatitis B Surface Antigen (HBsAG) and Human Immunodeficiency Virus (HIV) Among Pregnant Women in Calabar, Cross River State, Nigeria. J Med Lab Sci. 2010;19(1):23-30.

53. Ya'aba Y, Mohammed SB, Olatunji KT, Abubakar A, Usoroh M, Daniel OC, Nfongeh JF. 2019. Prevalence of hepatitis B and C among HIV infected pregnant women attending care and treatment at National Institute for Pharmaceutical Research and Development (NIPRD), Abuja, Nigeria. Microbiol Res J Int. 1-8.

54. Thumbiran NV, Moodley D, Parboosing R, Moodley P. 2014. Hepatitis B and HIV co-infection in pregnant women: indication for routine antenatal hepatitis B virus screening in a high HIV prevalence setting. SAMJ: South Afr Med J 104(4): 307-9.

55. Abongwa LE, Clara AM, Edouard NA, Ngum NH. Sero-Prevalence of human immunodeficiency virus (HIV) and Hepatitis B virus (HBV) CoInfection among pregnant women residing in Bamenda Health District, Cameroon. Int J Curr Microbiol Appl Sci. 2015:4(12):473-83.

56. Fomulu NJ, Morfaw FL, Torimiro JN, Nana P, Koh MV, William T. Prevalence, correlates and pattern of Hepatitis B among antenatal clinic attenders in Yaounde-Cameroon: is perinatal transmission of HBV neglected in Cameroon? BMC Pregnancy Childbirth. 2013;13(1):158.

57. Kfutwah AK, Tejiokem MC, Njouom R. A low proportion of HBeAg among HBsAg-positive pregnant women with known HIV status could suggest low perinatal transmission of HBV in Cameroon. Virol J. 2012;9(1):1-4

58. Noubiap JJN, Nansseu JRN, Ndoula ST, Bigna JJR, Jingi AM, FokomDomgue J. Prevalence, infectivity and correlates of hepatitis B virus infection among pregnant women in a rural district of the Far North Region of Cameroon. BMC Public Health. 2015;15(1):1-7.

59. Tanjong RE, Teyim P, Kamga HL, Neba ES, Nkuo-Akenji T. Seroprevalence of Human Immunodeficiency Virus and hepatitis viruses and their correlation with CD4 T-cell lymphocyte counts in pregnant women in the Buea Health District of Cameroon. Int J Biol Chem Sci. 2016;10(1):219-31.

60. Dionne-Odom, J., Mbah, R., Rembert, N. J., Tancho, S., Halle-Ekane, G. E., Enah, C., Tita AT. 2016. Hepatitis B, HIV, and syphilis seroprevalence in pregnant women and blood donors in Cameroon. Infect Dis Obstet Gynecol. 2016.

61. Mpody C, Thompson P, Tabala M, Ravelomanana NLR, Malongo F, Kawende B, CQI-PMTCT Study Team. 2019. Hepatitis B infection among pregnant and post-partum women living with HIV and on antiretroviral therapy in Kinshasa, DR Congo: a cross-sectional study. PloS One, 14(5), e0216293.

62. Landes M, Newell ML, Barlow P, Fiore S, Malyuta R, Martinelli P, Tibaldi C (2008). Hepatitis B or Hepatitis C co-infection in HIV-infected pregnant women in Europe. HIV Med 9(7), 526-34. 
63. Mave V, Kadam D, Kinikar A, Gupte N, Bhattacharya D, Bharadwi R, Thio C. 2014. Impact of maternal hepatitis B virus co-infection on mother-to-child transmission of HIV. HIV Med. 15(6), 347-54.

64. Chatterjee S, Ravishankar K, Chatterjee R, Narang A, Kinikar A. Hepatitis B prevalence during pregnancy. Indian Pediatr. 2009;46(11):1005.

65. Sahaf F, Tanomand A, Montazam H, Sany AA. Seroprevalence of hepatitis $C$, hepatitis $B$ and $H I V$ and co-infection among pregnant women: a retrospective study in 2006 at Malekan city, Iran. Res J Med Sci. 2007;1(2):138-41.

66. Madendağ Y, Madendağ İç: Çelen Ş, Ünlü S, Danişman N. . Seroprevalence of Hepatitis B, Hepatitis C And HIV at whole obstetric and gynecologic patients who applied our hospital. J Gynecol Obst. 2007;17:442-6.

67. Tekay F, Özbek E. Hepatitis B, Hepatitis C and Human Immunodeficiency Virus seropositivities in women admitted to Şanlıurfa Gynecology And Obstetrics Hospital. Mikrobiyol Bült. 2006;40:369-72.

68. Liaw Y-F, Chu C-M. Hepatitis B virus infection. Lancet. 2009;373(9663):582-92.

69. Tagny CT, Owusu-Ofori S, Mbanya D, Deneys V. The blood donor in subSaharan Africa: a review. Transfus Med. 2010:20(1):1-10

70. Frambo AA, Besong JA, Peter NF, Ndumbe PM. 2014. Prevalence of HBsAg and knowledge about hepatitis B in pregnancy in the Buea Health District, Cameroon. a cross-sectional study. BMC Res Notes, 7:394.

71. Migita K, Miyazoe S, Maeda Y, Daikoku M, Abiru S, Ueki T, Eguchi K 2005. Cytokine gene polymorphisms in Japanese patients with hepatitis B virus infection-association between TGF- b 1 polymorphisms and hepatocellular carcinoma. J Hepatol. 42, 505-10.

72. Gusatti, C. de S., Costi, C., Rubia, M., Halon, L., Grandi, T., Ferrari, A., Rodenbusch, R. (2016). Association between cytokine gene polymorphisms and outcome of hepatitis B virus infection in southern Brazil Association Between Cytokine Gene Polymorphisms and Outcome of Hepatitis B Virus Infection in. J Med Virol. (March).

73. Yang H, Lu S, Liaw Y, You S, Sun C, Wang L. Hepatitis B e antigen and the risk of hepatocellular carcinoma. N Engl J Med. 2002;347:168-74.

74. Iloeje U, Yang H, Su J, Jen C, You S, Chen C. Predicting cirrhosis risk based on the level of circulating hepatitis B viral load. Gastroenterology. 2006:130:678-86.

75. Chen C, Yang H, Su J, Jen C, You S, Lu S. Risk of hepatocellular carcinoma across a biological gradient of serum hepatitis B virus DNA level. JAMA. 2006;295:65-73.

76. YousifM, Mudawi H, Bakhiet S. Molecular characterization of hepatitis B virus in liver disease patients and asymptomatic carriers of the virus in Sudan. BMC Infect Dis. 2013;13:328.

77. Soriano V, Mocroft A, Peters L, Rockstroh J, Antunes F, Kirkby N, de Wit S, Monforte Ad, Flisiak R, Lundgren J. Predictors of hepatitis B virus genotype and viraemia in HIV infected patients with chronic hepatitis B in Europe. J Antimicrob Chemother 2010; 65: 548-55

78. Sanchez-Tapias J, Costa J, Mas A, Bruquera M, Rodes J. Inuence of hepatitis $B$ virus genome on the long-term outcome of chronic hepatitis $B$ virus in western patients. Gastroenterology. 2002;123:1848-56.

79. Kafeero MH, Sendagire H, Ocama P, Ndagire D. 2019. Host and viral factors associated with hepatitis B clinical outcomes in chronic infection-review article. Int J Pure Med Res. 4(3): 9-15

80. Man-Fung Y, Ching-Lung L. Treatment of chronic hepatitis B: evolution over two decades. J Gastroenterol Hepatol. 2011;26(Suppl. 1):138-43.

81. Zampino R, Boemio A, Sagnelli C, Alessio L, Adinolfi LE, Sagnelli E, Coppola N. Hepatitis B virusburden in developing countries. World J Gastroenterol. 2015;21:11941.

82. Stabinski L, Barnhart M, Kahn RJ, Hamm TE. Prevalence of HIV and hepatitis $B$ virus co-infection in sub-Saharan Africa and the potential impact and program feasibility of hepatitis B surface antigen screening in resource limited settings. J Acquir Immune Defic Syndr. 2015;3:274-85.

83. Sa'nchez, L., Tanaka, Y., Maldonado, M., Mizokami, M., \& Panduro, A. . Difference of hepatitis $B$ virus genotype distribution in two groups of Mexican patients with different risk factors. High prevalence of genotype $\mathrm{H}$ and $\mathrm{G}$. Intervirology. 2007;50:8-15.

84. Shao ER, Mboya IB, Gunda DW, Ruhangisa FG, Temu EM, Nkwama ML, Maro VP. Seroprevalence of hepatitis B virus infection and associated factors among healthcare workers in northern Tanzania. BMC Infect Dis. 2018;18(1):474.

85. Kafeero HM, Ndagire DN, Nanyingi HN, Sendagire HS. Host genetic factors associated with hepatitis $B$ virus infection and progression to chronic disease: A systematic review and Meta analysis. BMC Immunol. 2019. https ://doi.org/10.21203/rs.2.12164/v1.
86. Ntagirabiri R, Niyongabo T, Ndayiragije E, Baransaka. . The prevalence of hepatitis B in Burundi national survey. Afr J Hepatol Gastroenterol. 2013:7:199-2035.

87. Tanrıverdi EÇ, Özkurt Z, Kadıoğlu BG, Alay H, Çalıkoğlu O, Koca Ö, Kamalak Z. Seroprevalence of hepatitis B, hepatitis C, and HIV in pregnant women from Eastern Turkey. Turkish J Gastroenterol. 2019;30(3):260.

88. Furuncuoglu Y, Bolukbas FF, Bolukbas C, Torun P, Ozturk R. Changes in the prevalence of HBV infection in pregnant women in Turkey between 1995 and 2015: a 20-year evaluation. Postgrad Med J. 2016;92(1091):510-3.

89. Mohammadi M, Talei G, Sheikhian A, Ebrahimzade F, Pournia Y, Ghasemi E, Boroun $\mathrm{H}$. Survey of both hepatitis B virus (HBsAg) and hepatitis $C$ virus (HCV-Ab) coinfection among HIV positive patients. Virology J. 2009;6(1):202

90. Nkiru EC, Edo AD, Obiora NG, Igwe CU. 2004. The seroprevalence of hepatitis B surface antigen and human immunodeficiency virus among pregnant women in Anambra State, Nigeria.

91. World Health Organization (WHO). HIV in Africa. Weekly Epidemiol Rec. 1996:71(27):205-12.

92. Gasim GI, Murad IA, Adam I. Hepatitis B and C virus infections among pregnant women in Arab and African countries. J Infect Dev Countries. 2013;7(08):566-78.

93. Van der Veen YJJ, Voeten de Zwart HACM, Richardus JH. Awareness, knowledge and self reported test rates regarding Hepatitis B in Turkish-Dutch a survey. BMC Public Health. 2010;10:512.

94. Zhang TC, Pan FM, Zhang LZ, Gao YF, Zhang ZH, Gao J, Ge R, Mei Y, Shen BB, Duan ZH, Li X. A meta-analysis of the relation of polymorphism at sites - 1082 and -592 of the IL-10 gene promoter with susceptibility and clearance to persistent hepatitis $B$ virus infection in the Chinese population. Infection. 2011;39(1):21-7.

95. Talaat RM, Dondeti MF, El-Shenawy SZ, Khamiss OA. Association between IL-10 gene promoter polymorphism and hepatitis B viral infection in an Egyptian population. Biochem Genet. 2014;52(9-10):387-402.

96. Hoan N, Khuyen N, Giang D. Vitamin D receptor Apal polymorphism associated with progression of liver disease in Vietnamese patients chronically infected with hepatitis B virus. BMC Med Genet. 2019;20:201.

97. Huang YW, Liao YT, Chen W, Chen CL, Hu JT, Liu CJ, Kao JH. Vitamin D receptor gene polymorphisms and distinct clinical phenotypes of hepatitis $B$ carriers in Taiwan. Genes Immun. 2010;11(1):87-93.

98. Claiborne DT, Scully EP, Palmer CD, Prince JL, Macharia GN, Kopycinski J, Douek D. Protective HLA alleles are associated with reduced LPS levels in acute HIV infection with implications for immune activation and pathogenesis. PLoS Pathog. 2019;15(8):e1007981.

99. Huang YH, Liao SF, Khor SS, Lin YJ, Chen HY, Chang YH, Huang C. Large-scale genome-wide association study identifies HLA class II variants associated with chronic HBV infection: a study from Taiwan Biobank. Aliment Pharmacol Ther. 2020;52(4):682-91.

100. Dwyer-Lindgren L, Cork MA, Sligar A, Steuben KM, Wilson KF, Provost NR, Biehl MH. Mapping HIV prevalence in sub-Saharan Africa between 2000 and 2017. Nature. 2019:570(7760):189-93.

101. Prudden HJ, Beattie TS, Bobrova N, Ponovska-Griffiths J, Mukandavire Z, Gorgens $M$, et al. 2015. Factors associated with variations in population HIV prevalence across West Africa: findings from an ecological analysis. PLOS ONE 10 (12)

102. Hegdahl HK, Fylkenes KM, Sandoy IF. 2016. Sex differences in HIV prevalence persist over time: evidence from 18 Countries in sub-Saharan Africa. PLoS ONE 11(12)

103. UNAIDS. Gap Report. Geneva: UNAIDS, 2013.

104. Centers for Disease Control and Prevention. 2016. Advisory committee on immunization practices (ACIP). Recommended Child and Adolescent Immunization Schedules for Ages, 18

105. Tsebe KV, Burnett RJ, Hlungwani NP, Sibara MM, Venter PA, Mphahlele MJ. The first five years of universal hepatitis B vaccination in South Africa: evidence for elimination of HBsAg carriage under-5-year-olds. Vaccine. 2001;19(28-29):3919-26.

\section{Publisher's Note}

Springer Nature remains neutral with regard to jurisdictional claims in published maps and institutional affiliations. 